University of South Florida

DIGITAL COMMONS

Digital Commons @ University of

@ UNIVERSITY OF SOUTH FLORIDA

South Florida

$6-2020$

\title{
In Situ Measurements of Circulation Features Influencing Cross- Shelf Transport Around Northwest Cuba
}

\author{
Matthieu Le Hénaff \\ University of Miami \\ Vassiliki H. Kourafalou \\ University of Miami \\ Yannis Androulidakis \\ University of Miami \\ Ryan H. Smith \\ Atlantic Oceanographic and Meteorological Laboratory \\ HeeSook Kang \\ University of Miami
}

See next page for additional authors

Follow this and additional works at: https://digitalcommons.usf.edu/msc_facpub

Part of the Life Sciences Commons

\section{Scholar Commons Citation}

Le Hénaff, Matthieu; Kourafalou, Vassiliki H.; Androulidakis, Yannis; Smith, Ryan H.; Kang, HeeSook; Hu, Chuanmin; and Lamkin, John T., "In Situ Measurements of Circulation Features Influencing Cross-Shelf Transport Around Northwest Cuba" (2020). Marine Science Faculty Publications. 1877.

https://digitalcommons.usf.edu/msc_facpub/1877

This Article is brought to you for free and open access by the College of Marine Science at Digital Commons @ University of South Florida. It has been accepted for inclusion in Marine Science Faculty Publications by an authorized administrator of Digital Commons @ University of South Florida. For more information, please contact digitalcommons@usf.edu. 


\section{Authors}

Matthieu Le Hénaff, Vassiliki H. Kourafalou, Yannis Androulidakis, Ryan H. Smith, HeeSook Kang, Chuanmin Hu, and John T. Lamkin 


\author{
RESEARCH ARTICLE \\ 10.1029/2019JC015780 \\ Key Points: \\ - A Cuban ANticyclonic (CubAN) \\ eddy typical of the ocean circulation \\ along northwest Cuba was observed \\ in situ for the first time in 2016 \\ - Novel observations near \\ northwestern Cuba show how \\ CubANs and cyclonic eddies help \\ advect upwelled waters offshore \\ - Along the western tip of Cuba, \\ offshore transport of coastal waters \\ to the Gulf of Mexico interior is \\ dependent on the Loop Current state
}

Correspondence to:

M. Le Hénaff,

m.lehenaff@miami.edu

Citation:

Le Hénaff, M., Kourafalou, V. H., Androulidakis, Y., Smith, R. H., Kang, H., Hu, C., \& Lamkin, J. T. (2020). In situ measurements of circulation features influencing cross-shelf transport around northwest Cuba. Journal of Geophysical Research: Oceans, 125, e2019JC015780. https:// doi.org/10.1029/2019JC015780

Received 14 OCT 2019 Accepted 2 JUN 2020 Accepted article online 5 JUN 2020

\section{In Situ Measurements of Circulation Features Influencing Cross-Shelf Transport Around Northwest Cuba}

\author{
Matthieu Le Hénaff ${ }^{1,2}$ (D), Vassiliki H. Kourafalou ${ }^{3}$ D, Yannis Androulidakis ${ }^{3}$, Ryan H. Smith² ${ }^{2}$, \\ HeeSook Kang ${ }^{3}$ (D), Chuanmin $\mathrm{Hu}^{4}$ iD, and John T. Lamkin ${ }^{5}$ \\ ${ }^{1}$ Cooperative Institute for Marine and Atmospheric Studies (CIMAS), University of Miami, Miami, FL, USA, ${ }^{2}$ Atlantic \\ Oceanographic and Meteorological Laboratory (AOML), NOAA, Miami, FL, USA, ${ }^{3}$ Rosenstiel School of Marine and \\ Atmospheric Science (RSMAS), University of Miami, Miami, FL, USA, ${ }^{4}$ College of Marine Science, University of South \\ Florida, St. Petersburg, FL, USA, ${ }^{5}$ Southeast Fisheries Science Center (SEFSC), NOAA, Miami, FL, USA
}

\begin{abstract}
We analyzed circulation processes sampled in the Gulf of Mexico in May 2016 by the National Oceanic and Atmospheric Administration (NOAA) Ship Nancy Foster. This data set is one of the first in situ surveys in Cuban waters available to the international community. Along northwest Cuba, these data suggested coastal upwelling and revealed, for the first time, a $\sim 50 \mathrm{~km}$ diameter Cuban ANticyclonic (CubAN) eddy and a $\sim 25 \mathrm{~km}$ diameter cyclonic eddy, which together advected upwelled waters offshore. The CubAN eddy was associated with downwelling, and the cyclonic eddy with upwelling. At the western tip of Cuba, local currents were predominantly anticyclonic, presumably due to the proximity of the retracted Loop Current, with limited export of coastal waters. Conversely, additional data from two cruises when the Loop Current was extended showed cyclonic circulation within upwelling filaments extending far offshore. These processes are important, as they can potentially entrain marine organism larvae from local reefs into the Loop Current system and to other reef ecosystems of the region. They might also affect the transport of pollutants, as hydrocarbons in case of a spill in Cuban waters. The 2016 cruise took place after the shedding of a Loop Current Ring, which involved an unusually large $(\sim 250 \mathrm{~km})$ cyclonic frontal eddy. The eddy signature was observed down to 1,200 $\mathrm{m}$ depth, deeper than the Loop Current. A surface drifter revealed a low relative vorticity $(0.19 \mathrm{f})$ inside the eddy. Along its southern edge, filaments exported from the Campeche Bank were associated with high relative chlorophyll a at 3,060 $\mathrm{m}$ depth.
\end{abstract}

Plain Language Summary We analyzed observations sampled in the southeastern Gulf of Mexico in May 2016 by the National Oceanic and Atmospheric Administration (NOAA) Ship Nancy Foster. Along northwest Cuba, these data showed the presence of coastal upwelling, when cold and nutrient-rich waters are pulled to the surface along the coast under the action of the winds. A pair of ocean vortices was observed, one rotating clockwise and one counterclockwise, which together transported the upwelled waters from the coast offshore. At the western tip of Cuba, the offshore transport of coastal waters appears dependent on the state of the Loop Current, the main current of the region. This finding was based on in situ observations from two additional research cruises and satellite data. When the Loop Current is flowing close to Cuba, the transport of coastal waters is limited, whereas when it is flowing further north inside the Gulf, coastal waters can be transported far offshore. The processes revealed by the study are thus important, since they can transport marine organism larvae from coral reefs along the Cuban coast into the dynamical current system of the Gulf of Mexico and the Straits of Florida. Similarly, these processes can transport pollutants in case of an accident in Cuban waters.

\section{Introduction}

Although a part of the widely studied Gulf of Mexico (GoM), the dynamics off northwest Cuba have not received much attention. Indeed, in situ observations had not been available to the international community until recently, because of geopolitical reasons. However, improvements in the relationship between the United States and Cuba in the Years 2014-2016 allowed for an increase in collaborative efforts to advance the studies of the oceanography of Cuban waters, and a few ground-breaking research cruises involving United States-based research vessels took place in Cuban waters during that period. This followed limited, ad hoc activities, as in the aftermath of the 2010 Deepwater Horizon oil spill, when scientists from the National Oceanic and Atmospheric Administration (NOAA) were granted access to survey Cuba's 


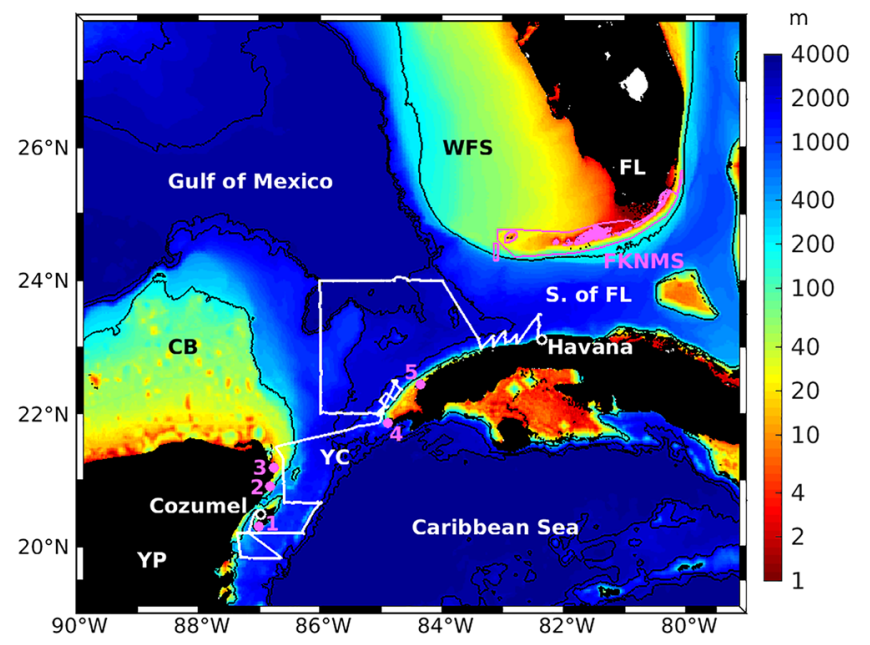

Figure 1. Bathymetry (m) of the southeastern Gulf of Mexico and northwestern Caribbean Sea. Black contours indicate the 200, 2,000, and $3,000 \mathrm{~m}$ isobaths. The white line is the track of the NOAA Ship Nancy Foster between Havana (Cuba) and the island of Cozumel (Mexico), both marked by a white circle with a central black dot, from 10 to 19 May 2016. We marked various features of interest for our study: The Straits of Florida (S. of FL) between Florida (FL), Cuba and the Bahamas, the Yucatan Channel (YC) between Mexico and Cuba, the West Florida Shelf (WFS), which is the wide continental shelf west of Florida, and the Campeche Bank (CB), which is another wide continental shelf north of the Yucatan Peninsula (YP) in Mexico. We also marked, in magenta, the marine protected areas near the regions sampled by the Nancy Foster: The Florida Keys National Marine Sanctuary (FKNMS, United States), the Parque Nacional Arrecifes de Cozumel (1, Mexico), the Parque Nacional Arrecife de Puerto Morelos (2, Mexico), the Parque Nacional Costa Occidental de Isla Mujeres, Punta Cancún y Punta Nizuc (3, Mexico), the Parque Nacional Península de Guanahacabibes (4, Cuba), and the Reserva Ecológica Los Pretiles (5, Cuba). The cape at the western tip of Cuba, at the end of the Guanahacabibes peninsula (4), is the Cape San Antonio. The shallow bay between (4) and (5) is the Gulf of Guanahacabibes.
Exclusive Economic Zone (EEZ), as they examined potential oil transport pathways (Smith et al., 2014). In November 2015, the United States and Cuba signed a Memorandum of Understanding (MOU) for marine protected areas (MPAs) conservation and management between the Parque Nacional Guanahacabibes in Cuba and the Florida Keys and Flower Garden Banks National Marine Sanctuaries in the United States. This MOU paralleled The Gulf of Mexico Large Marine Ecosystem, a binational effort between the United States, represented by NOAA, and Mexico (Wenzel et al., 2019). These trinational efforts acknowledge the fact that marine sanctuaries along the Loop Current (LC) system are connected by the ocean circulation, independently from national boundaries. In that context, two research cruises, conducted by NOAA's Atlantic Oceanographic and Meteorological Laboratory (AOML) and National Marine Fisheries (NMFS) Southeast Fisheries Science Center (SEFSC), in collaboration with Mexican and Cuban scientists, were conducted in 2015 and 2016 aboard the research vessel NOAA Ship Nancy Foster to help characterize larval fish distribution in the southeastern GoM, with extensive sampling in Cuban waters. Concurrently with the survey's trawls for larval fish, physical data were also collected, such as upper-water currents and vertical temperature and salinity profiles. The goal of the present study is to describe and analyze the main ocean circulation features and physical properties observed during the 2016 Nancy Foster cruise (hereafter NF16), which took place during 10-19 May 2016, between Havana, Cuba, and Cozumel, Mexico (Figure 1). The analysis of similar features during the May 2015 cruise by the Nancy Foster (hereafter NF15) and during a survey by the University of Miami (UM) and the Harbor Branch Oceanographic Institute (Florida Atlantic University) aboard UM's R/V F.G. Walton Smith in May 2017 (hereafter WS17) will allow us to put these results in perspective.

Figure 1 shows the locations of various MPAs in the region sampled during NF16. Along the Mexican coast, the Parque Nacional Arrecifes de Cozumel, the Parque Nacional Arrecife de Puerto Morelos, and the Parque Nacional Costa Occidental de Isla Mujeres, Punta Cancún y Punta Nizuc are all located along the Yucatan Peninsula, just south of the Yucatan Channel that connects the GoM to the Caribbean Sea. Along the Cuban coast, the Parque Nacional Guanahacabibes and the Reserva Ecológica Los Pretiles are located on the eastern side of the Yucatan Channel, at the western tip of the island. In the United States, the Florida Keys National Marine Sanctuary (FKNMS) covers the entire Florida Keys reef tract ( $270 \mathrm{~km}$ long). All these MPAs host rich coral reef ecosystems that are essential for the health and biodiversity of the GoM and Caribbean Sea (e.g., Baur et al., 2017; Miloslavich et al., 2010; Valderrama et al., 2018). Fish and coral populations within the reefs of the region are connected through larval transport, as the larval stage is the primary vector of dispersal for the majority of benthic marine organisms. This population connectivity is mostly driven by the ocean circulation. In addition to hosting rich ecosystems, Cuba's EEZ inside the GoM and the Straits of Florida has been considered as an area of oil exploration, while it is also an area of heavy marine traffic, as the crossroads between GoM, the Caribbean Sea, and the Atlantic Ocean. This raises concerns about the impacts a potential oil spill would have, not only along the coasts of Cuba but also inside the GoM and along the coasts of South Florida, Campeche Bank, and the Bahamas.

The GoM regional circulation is dominated by the LC, which is a branch of the North Atlantic western boundary current system, known as the Gulf Stream. It enters the GoM via the Yucatan Channel and exits the GoM through the Straits of Florida where it becomes the Florida Current, before becoming the Gulf Stream as it enters the Atlantic Ocean. Inside the GoM, the LC has a variable pathway, from a retracted position in which it flows directly from the Yucatan Channel to the Straits of Florida to an extended position where it flows to the north of the basin, approaching the Mississippi Delta, before retroflecting 
southeastward toward the Straits of Florida. Once extended, the LC sheds a large, anticyclonic eddy called a Loop Current eddy (LC eddy), or Ring, which causes the LC to return to its retracted position. The shedding of LC eddies is not periodic, and the separation period between two eddy formations varies between 0.5 and 18.5 months with peaks at 6, 9, and 11.5 months (Dukhovskoy et al., 2015; Leben, 2005). Furthermore, the LC can sometimes stay retracted for prolonged periods of time, delaying the LC extension and the shedding of an LC eddy, as was reported during 1998-1999 by Zavala-Hidalgo, Morey, et al. (2006). The variable nature of the LC extension directly affects the connectivity between coastal regions in the GoM: An extended LC favors the transport of Mississippi River waters from the northern GoM to the Straits of Florida, while a retracted LC allows for the transport of coastal waters from the Campeche Bank to the Straits of Florida (Androulidakis et al., 2019; Otis et al., 2019; Schiller \& Kourafalou, 2014). These changes in the LC configuration not only affect the GoM currents but also the organisms and other materials they may carry. Therefore, these variations have biophysical implications, such as the connectivity patterns of marine organism populations or the transport of nutrients and pollutants.

The shedding of LC eddies, by which the LC goes from an extended to a retracted position, is influenced by the interactions between the LC and cyclonic eddies at the edge of the LC, called LC frontal eddies (Chérubin et al., 2006; LCFEs, Fratantoni et al., 1998; Le Hénaff et al., 2012; Schmitz, 2005). These mesoscale eddies usually have a diameter of 80 to $120 \mathrm{~km}$ and extend to at least 1,000 m depth (Vukovich \& Maul, 1985). Moorings have recorded decreased temperatures, associated with the upwelling inside cyclonic LCFEs, to depths of 1,500 m (Androulidakis et al., 2014). A synthesis of LCFE surface characteristics was derived by Le Hénaff et al. (2014).

More recently, in addition to the cyclonic LCFEs, GoM anticyclonic eddies that are different from the LC eddies were identified in the GoM as playing a role in the LC evolution. They are found at the southern side of the LC, along Cuba, and were thus named CubANs, for Cuban ANticyclones (Kourafalou et al., 2017). These anticyclonic eddies are still mesoscale, although generally smaller than the LC eddies. Based on modeling, satellite, and drifter data, Kourafalou et al. (2017) showed that such anticyclonic eddies can form at the base of the LC (Type A CubANs) and that some of them can be detached from the LC and advected eastward in the Straits of Florida (Type B CubANs). They also found that most CubAN eddies, especially Type A, were observed when the LC was retracted or detached from a newly formed LC eddy but that some CubAN eddies, mainly Type B, were present when the LC was extended and contributed to further its northern extension. Kourafalou et al. (2017) also showed that the evolution of CubANs tends to be influenced by coastal upwelling, which brings cold and nutrient-rich waters to the surface and entrains them offshore. These filaments of upwelled waters allow the separation of CubAN eddies from the base of the LC (Type B CubANs), and they also tend to form small, cyclonic eddies along the coast of Cuba. Although these circulation features were previously described using satellite data and numerical modeling, they have not yet been studied with in situ data, due to the lack of field observations available to non-Cuban scientists.

The present study aims at describing and analyzing various ocean circulation features sampled during NF16, within the LC system as well as along the Campeche Bank and the northwestern Cuban coast. This work fills an important gap in the understanding of GoM dynamics, especially the evolution of the LC system in the southeastern GoM. Using this unique data set, we want to address the following questions: What were the characteristics of the LC system during the 2016 cruise? What are the horizontal and vertical signatures of typical coastal circulation features along the Campeche Bank and along northwestern Cuba, which influence cross-shelf transport? What are the conditions that favor the setup of these circulation features?

After presenting the observational data we used in our study (section 2), the present article describes the ocean circulation features observed prior to and during NF16 surveys at various locations in the southeastern GoM and discusses these features, using additional data such as those from the 2015 and 2017 cruises (section 3), before concluding (section 4). The results related to the larval fish distribution and characterization from the 2016 cruise will be presented in a separate study.

\section{Ocean Observations and Atmospheric Model Data}

The primary data used in this study are the NF16 in situ measurements. We analyzed the vertical profiles of temperature, salinity, and relative chlorophyll a collected with a SeaBird 911plus conductivity-temperaturedepth (CTD) system aboard the ship. In addition to the discrete CTD data collected, we also analyzed the 
upper-ocean currents continuously measured by a hull-mounted (shipboard) Teledyne RD Instruments (TRDI) $150 \mathrm{kHz}$ Ocean Surveyor acoustic Doppler current profiler (SADCP) throughout the survey. This ocean current velocity data set, along with a similar data set from NF15, were both postprocessed using the University of Hawaii's Common Ocean Data Access System (CODAS) software package. We also used a third SADCP velocity data set, recorded using a TRDI $75 \mathrm{kHz}$ Ocean Surveyor SADCP on WS17.

In addition to data from onboard instruments, we analyzed data from Surface Velocity Program (SVP) Lagrangian drifters of the Global Drifter Program. These drifters have a center of mass at $15 \mathrm{~m}$ below the surface thanks to a nylon holey sock drogue (Lumpkin \& Pazos, 2007). Three such drifters, provided by NOAA/AOML, were deployed during NF16 (ID \# 139942, 139946, and 139947). We also analyzed the trajectory of an additional SVP drifter deployed along the northern Cuban coast in August 2016 (ID \# 63704970).

These in situ observations are the main data used in this study. However, we also used satellite data to identify regional and local conditions relevant to the analysis of the in situ data. We used satellite-derived maps of chlorophyll a concentration (hereafter Chl-a) to identify near-surface circulation features of interest. The 1-km resolution daily snapshot Chl-a images can better reveal near-surface circulation features than other coarser-resolution satellite data products. The Chl-a estimates were derived from a hybrid algorithm to quantify the relative magnitude of blue, green, and red light reflected from the ocean (Hu et al., 2012; O'Reilly et al., 2000), where most optical signals come from the top layer of the ocean (down to about one optical depth, approximately 50-70 $\mathrm{m}$ in oligotrophic oceans and 10-30 $\mathrm{m}$ in more productive shelf waters for blue-green light, with each depth's signal weighted by an exponentially delaying function). The oligotrophic LC waters are characterized by low productivity and thus low Chl-a, while more productive shelf waters are associated with higher Chl-a values. Furthermore, cyclonic eddies, such as the LCFEs, are associated with upwelling that can bring nutrients closer to the surface, leading to an increase in the surface Chl-a (McGillicuddy et al., 1998). For these reasons, surface Chl-a is a useful tool for defining the locations of ocean circulation features in the region, and it has been used on several occasions to study the path of the various water masses at the surface of the GoM (e.g., Androulidakis et al., 2019; Hu \& Muller-Karger, 2008; Muller-Karger et al., 1991; Otis et al., 2019; Soto et al., 2009). Whenever possible, we used the NASA standard 1-km resolution Chl-a maps derived from the Moderate Resolution Imaging Spectrometer (MODIS) on Aqua and Terra NASA satellites. When these maps contain significant data gaps due to the presence of strong sun glint, thin clouds, or thick aerosols, we used the machine learning approach by Chen et al. (2019) to estimate Chl-a data from these image pixels to fill the data gaps.

The second type of satellite observational data we used are the Maps of Absolute Dynamic Topography (MADT) data, from Archiving, Validation and Interpretation of Satellite Oceanographic data (AVISO). We used the Delayed-Time products interpolated on a $0.25^{\circ}$ spatial grid with daily estimates. Through geostrophy, gradients in MADT are associated with geostrophic currents, and closed contours of MADT can be associated with mesoscale eddies.

Finally, since there are no meteorological observations available in Cuban waters during our study period, we used model data for winds provided by the European Centre for Medium-Range Weather Forecasts (ECMWF), with spatial resolution of $0.125^{\circ}$, in certain areas of interest in the study region.

\section{Results and Discussion}

Following the description of the ocean conditions prior to the cruise (section 3.1), this section describes the circulation features that were sampled during NF16 and analyzes them using additional data, in particular, from NF15 and WS17. The description of the sampled features is split in different regions and processes of interest.

\subsection{Regional Ocean Conditions Prior to the Cruise}

The weeks preceding the May 2016 survey were characterized by the detachment and separation of an LC eddy (Figure 2). On 5 April, a large cyclonic LCFE on the east of the extended LC, at about $25^{\circ} \mathrm{N}, 85^{\circ} \mathrm{W}$, led to the severe necking down of the LC (Figure $2 \mathrm{a}$ ). At the same date, at $23^{\circ} \mathrm{N}, 86^{\circ} \mathrm{W}$ along the Campeche Bank, the LC formed a slight meander, which suggests the presence of a second, smaller cyclonic LCFE, as is often observed in that area. The presence of such LCFEs along the Campeche Bank is important, as they have been shown to sometimes take part in the detachment of LC eddies from the LC 




Figure 2. Surface chlorophyll a concentration (Chl-a, colors, $\mathrm{mg} / \mathrm{m}^{3}$ ) observed from MODIS Aqua and Terra satellites, on (a) 5, (b) 21, and (c) 28 April and (d) 5 May 2016. Superimposed are the anomalies, on the corresponding dates, of the Maps of Absolute Dynamic Topography (MADT) with respect to the spatial average of the MADT over the Gulf of Mexico on the same day (red contours every $10 \mathrm{~cm}$ ), derived from satellite altimetry. The positive anomalies of MADT are in dashed lines; the negative anomalies are in continuous lines. Through geostrophy, closed dashed contours are associated with anticyclonic eddies, and closed continuous contours are associated with cyclonic eddies. Black contours indicate the 200, 2,000, and 3,000 $\mathrm{m}$ isobaths.

(Androulidakis et al., 2014; Athié et al., 2012; Le Hénaff et al., 2014; Schmitz, 2005; Zavala-Hidalgo et al., 2003). On 21 April, the LCFE along the Campeche Bank extended far northeastward and grew substantially, as its size then equaled the size of the LCFE on the east of the LC (Figure 2b). Both LCFEs were in the process of merging at that date, "squeezing" the LC neck and contributing to the separation of the LC eddy from the base of the LC, which retracted to the south. On 28 April, the eddy merging continued, forming a larger cyclonic eddy centered along the Campeche Bank (Figure 2c). On 5 May, a few days prior to the start of the survey, this newly formed LCFE, approximately centered at $23.5^{\circ} \mathrm{N}$, $86^{\circ} \mathrm{W}$ along the Campeche Bank, had a near-circular shape (Figure 2d). More notably, it had very large dimensions, roughly $250 \mathrm{~km}$ diameter, which is much larger than the 80 to $120 \mathrm{~km}$ diameter usually observed for LCFEs (Le Hénaff et al., 2014; Vukovich \& Maul, 1985). Although large LCFEs are often observed north of the retracted LC, they are usually found between $25^{\circ} \mathrm{N}$ and $26^{\circ} \mathrm{N}$ (Le Hénaff et al., 2014; Zavala-Hidalgo et al., 2002; Zavala-Hidalgo, Morey, et al., 2006), that is, to the north of the present eddy. As a result of the unusual position and size of the newly formed LCFE, the LC had a southwest-northeast direction when it entered the GoM, and it flowed northeastward along the northwestern coast of Cuba, which is unusual compared to the more common LC pattern in which the LC flows northward along the Campeche Bank. On 5 May also, the LC formed a limited northward bulge between the large LCFE and the West Florida Shelf, before entering the Straits of Florida and continuing its path as the Florida Current (Figure 2d). The conditions during NF16 were thus marked by LC eddy 


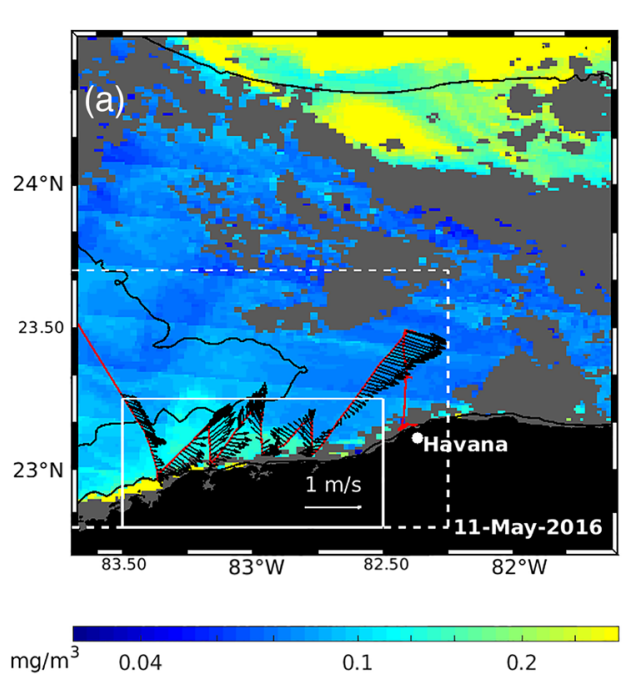

(d) $10 \mathrm{~m} / \mathrm{s}$
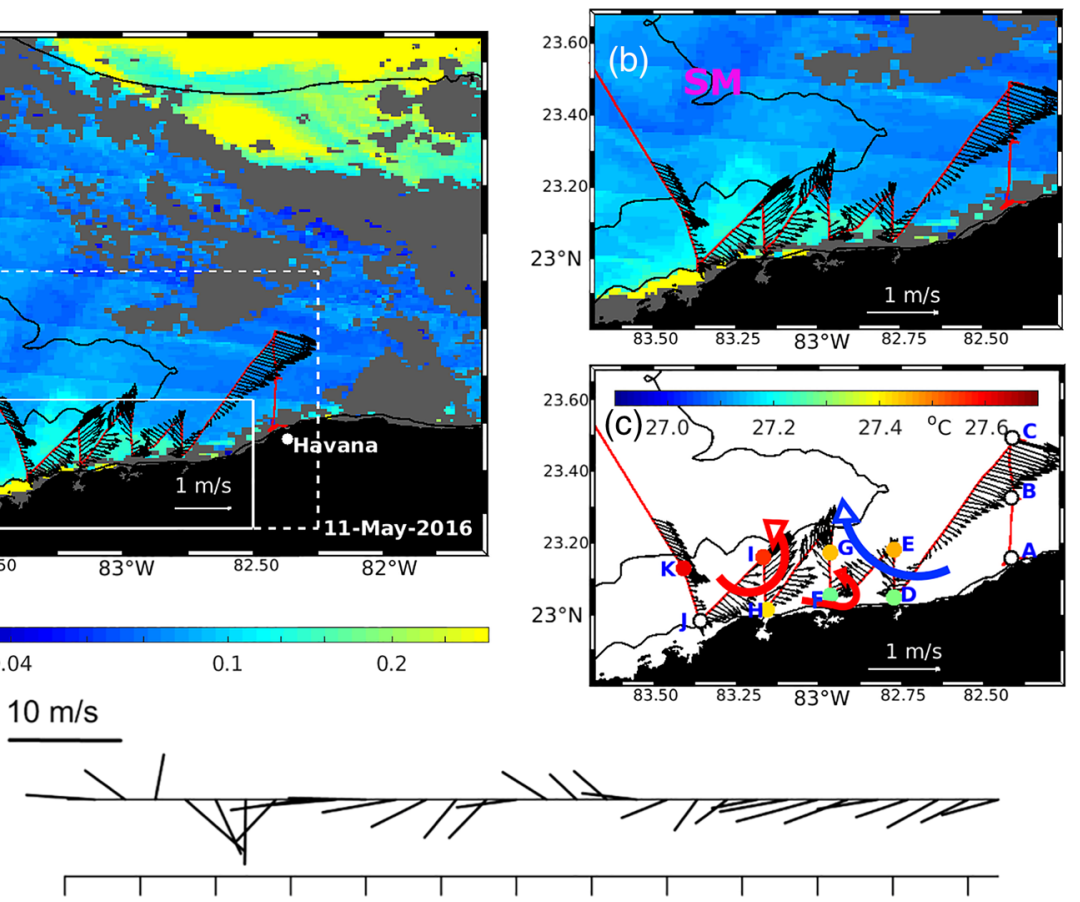

05/01/16 $\quad 05 / 06 / 16 \quad 05 / 11 / 16 \quad 05 / 16 / 16 \quad 05 / 21 / 16 \quad 05 / 26 / 16 \quad 05 / 31 / 16$

Figure 3. (a) Surface chlorophyll a (Chl-a, colors, $\mathrm{mg} / \mathrm{m}^{3}$ ) observed from MODIS Terra on 11 May 2016. In red is the track of the NOAA Ship Nancy Foster during the 2016 cruise (NF16). The black arrows are the velocity vectors measured by the onboard SADCP, averaged between 18 and $30 \mathrm{~m}$ depth. A reference arrow is included in the figure. (b) Same as (a) but zoomed in the area marked by the dashed white rectangle in (a). The letters SM mark the location of a submesoscale cyclonic eddy inside the retracted Loop Current (see text for details). (c) NF16 track (red) with velocity vectors measured by the onboard SADCP, averaged between 18 and $30 \mathrm{~m}$ depth (black arrows). The stations where CTD samples were taken are marked with letters A to K. The sampling from Stations D to K, where coastal processes of interest are located, took approximately $17 \mathrm{hr}$. The names of the stations follow the chronological order of sampling. The color dots and associated color bar represent the temperature $\left({ }^{\circ} \mathrm{C}\right)$ measured at $10 \mathrm{~m}$ depth by NF16 CTD casts for Stations D to I and K. The schematic thick arrows represent circulation features identified from the observations (red: cyclonic, blue: anticyclonic). (a-c) Black contours indicate the 200 and 2,000 m isobaths. (d) Vectors of daily mean of winds over the area marked by a solid white rectangle in (a) from ECMWF data (at sea locations only), from 1 to 31 May 2016, with a reference arrow for $10 \mathrm{~m} / \mathrm{s}$ winds.

detachment and a newly retracted LC, in the presence of an especially large LCFE that was located at an unusually southern position along the Campeche Bank.

\subsection{Northwestern Cuban Coast Region}

On 10 May 2016, the NOAA Ship Nancy Foster departed from Havana harbor and headed north to collect data at three stations forming a line perpendicular to the coast (Stations A, B, and C; see Figure 3). After that transect was completed, on 11 May, the ship took a southwestward course toward the coast and performed four consecutive transects, following a saw-like pattern from east to west. Figure 3a shows the ship track, the near-surface current vectors measured by the onboard SADCP, and the Chl-a estimated by satellite on the same day. The northern part of the map in Figure 3a shows the shelf area just south of the Florida Keys, which is marked by large Chl-a values. South of this feature, the "blue" waters (with low Chl-a values) associated with the Florida Current suggest a predominant ocean flow from northwest to southeast, which is confirmed by the near-surface currents sampled after the initial meridional transect during NF16, between Stations C and D (Figure 3). The intensity of the currents in that part of the Straits of Florida decreased slowly as the ship got closer to the coast, suggesting that the Florida Current was away from the portion of the Cuban coastal waters sampled by the Nancy Foster in the following days.

Figure $3 \mathrm{~b}$ shows a zoom from Figure $3 \mathrm{a}$ on the area sampled by the ship. The Chl-a map shows a bulge of larger Chl-a values extending offshore by approximately $0.25^{\circ}$ of latitude $(\sim 25 \mathrm{~km})$, which was surveyed. 
Another feature of interest is the patch of very low Chl-a values, just north of the high Chl-a bulge, also visible in Figure 3a. This feature, which is centered at $\sim 23.5^{\circ} \mathrm{N}, 83.3^{\circ} \mathrm{W}$, is visible on other Chl-a satellite images around that date, as well as on satellite sea surface temperature maps on which it is associated with lower temperature than surrounding waters (not shown). These observations suggest that this feature is actually a submesoscale cyclonic eddy, marked with "SM" (for submesoscale) in Figure 3b. Such a cyclonic submeoscale eddy within the base of the LC has never been previously reported to our knowledge. Although the ship did not sample it, the satellite evidence is strong.

Figures $3 \mathrm{~b}$ and $3 \mathrm{c}$ show the details of the near-surface currents measured by the onboard SADCP. The current vectors reveal a complex pattern, formed by a pair of counterrotating features: an anticyclonic structure, observed between Stations D and G, and a cyclonic structure between Stations H and K. Figure 3c shows the station locations and a schematic of the circulation features. The anticyclonic structure is associated with a reversal of the near-surface currents measured by the onboard SADCP shortly before Station D was sampled. The pattern of the observed currents shows clockwise currents along approximately three fourths of a circle, suggesting the presence of an anticyclonic eddy, of roughly $50 \mathrm{~km}$ diameter (based on the veering of the current vectors between Stations D and G). Such anticyclonic currents forming a mesoscale eddy in the southern side of the Florida Current are the signature of a CubAN eddy, as described by Kourafalou et al. (2017). More precisely, such a mesoscale anticyclonic eddy separated from the main LC is a Type B CubAN. The NF16 data are the first in situ observations showing an anticyclonic eddy that is consistent with the definition of CubAN eddies, which were initially described with numerical modeling and remote sensing (Kourafalou et al., 2017). To the west of this anticyclonic eddy, the cyclonic structure sampled between Stations $\mathrm{H}$ and $\mathrm{K}$ was located mostly within the offshore bulge of high Chl-a waters. The pattern of the currents and the shape of the bulge of high Chl-a waters suggest the presence of a cyclonic eddy, of roughly $25 \mathrm{~km}$ diameter (the approximate size of the bulge of high Chl-a). An additional smaller cyclonic structure is also visible near the coast, just east of Station F, of much smaller dimension (roughly $10 \mathrm{~km}$, the width of the current reversal near Station F).

Near-surface temperature at each sampled station shows colder temperature at stations near the coast compared to the offshore stations, suggesting coastal upwelling. Near-surface currents show offshore currents along the central meridional transects (along F-G and H-I), in agreement with coastal upwelling. The wind data in that area confirm easterly (upwelling-favorable) winds during 9-12 May (Figure 3d). The presence of cyclonic circulation features west of the CubAN eddy is consistent with the results from Kourafalou et al. (2017), who showed that, under favorable wind conditions, upwelling filaments could form a cyclonic eddy that isolates a CubAN eddy from the base of the LC, as is observed here.

Figure 4 shows the vertical sections of temperature and meridional currents between Stations $\mathrm{H}$ and I (Figures $4 \mathrm{a}$ and $4 \mathrm{~d}$ ), $\mathrm{F}$ and $\mathrm{G}$ (Figures $4 \mathrm{~b}$ and $4 \mathrm{e}$ ), and D and $\mathrm{E}$ (Figures $4 \mathrm{c}$ and $4 \mathrm{f}$ ), from west to east. The vertical sections in temperature were linearly interpolated between individual CTD casts at each station. For each section, we estimated the mixed layer depth (MLD) as in de Boyer Montégut et al. (2004), that is, based on a temperature criterion, in which the MLD is equal to the depth where the sea temperature is equal to the temperature at $10 \mathrm{~m}$ depth decreased by $0.2^{\circ} \mathrm{C}$. The data between $\mathrm{J}$ and $\mathrm{K}$ are located west of the cyclonic eddy identified in Figure 3, and they are not presented in Figure 4. The section between Stations H and I is located inside the cyclonic structure. The section between Stations F and G covers the smaller cyclonic structure close to the coast, while its offshore part is associated with the offshore tail of the anticyclonic CubAN eddy identified in Figure 3c. Finally, the section between Stations D and E is located inside that anticyclonic eddy. We note here that the corresponding vertical sections of salinity and relative chlorophyll a along the meridional and zonal transects were also analyzed, but they did not provide additional information on the local dynamical features with respect to temperature data.

The temperature structure over the top $300 \mathrm{~m}$ along Section H-I reveals an offshore shoaling of the isotherms below $100 \mathrm{~m}$ depth (Figure 4a). This shoaling is consistent with an upwelling inside the cyclonic eddy. Figures $4 \mathrm{~b}$ and $4 \mathrm{c}$ show the temperature structure along Sections F-G and D-E, respectively, on which there was no clear meridional shoaling or deepening of isotherms between 100 and $300 \mathrm{~m}$ depth. Figure 4d shows the temperature and meridional current structure in the top 120 and $100 \mathrm{~m}$, respectively, along Section H-I, where the MLD deepened offshore from $\sim 60$ down to $~ 95 \mathrm{~m}$. Temperature data along this section show a shoaling of the isotherms near the coast in the upper layer, which is typical of coastal upwelling, with 

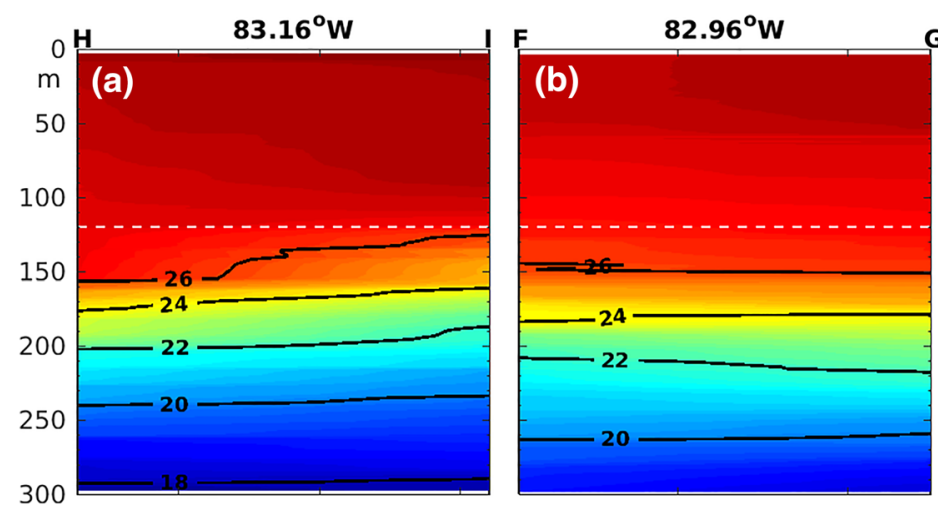

G D

$82.77^{\circ} \mathrm{W}$


Figure 4. (a) Vertical section along latitude $\left({ }^{\circ} \mathrm{N}\right)$ of temperature with contours $\left({ }^{\circ} \mathrm{C}\right)$ interpolated between two temperature profiles from CTD casts from NF16 at Stations H and I (see Figure 3), in the top $300 \mathrm{~m}$. The coast is on the left-hand side of the section. (b, c) Same as (a) between Stations F and G and between $\mathrm{D}$ and E, respectively. (d, e, f) Same as (a)-(c) but zoomed in the top $120 \mathrm{~m}$ (marked by a dashed white line in the top panels). Superimposed are the meridional currents measured by the onboard SADCP (blue contours every $8 \mathrm{~cm} / \mathrm{s}$ ), with continuous contours for northward, offshore currents and dashed contours for southward, inshore currents. (d-f) The solid gray line marks the mixed layer depth (see text for more details).

northward currents increasing offshore, reaching an amplitude larger than $30 \mathrm{~cm} / \mathrm{s}$. Figure $4 \mathrm{e}$ shows similar data along Section F-G, where the surface mixed layer was shallower than along Section H-I, with values close to $60 \mathrm{~m}$. Within the surface mixed layer, the meridional currents were predominantly northward with an acceleration offshore, whereas onshore currents were observed near the coast in the layer immediately below. This structure of offshore currents in the surface mixed layer, with onshore currents in the layer below, is typical of coastal upwelling. Along Section D-E (Figure 4f), the temperature structure was comparable to the one along Section F-G, but the meridional current did not show the same pattern of increasing northward in the surface mixed layer with onshore return flow below, as observed along F-G. The meridional sections thus suggest that coastal upwelling was taking place along Sections $\mathrm{H}-\mathrm{I}$ and F-G.

Figure 5 shows the vertical structure of temperature over the top $300 \mathrm{~m}$ along two sections parallel to the coast: coastal Section J-H-F-D-A (Figure 5a) and offshore Section K-I-G-E-B (Figure 5b). With the exception of a partial data loss at Station J (upper $80 \mathrm{~m}$ temperature), due to an instrument problem, the data thus cover important features. Along the offshore section (Figure 5b), the isotherms below $100 \mathrm{~m}$ depth shoaled at Station I, which is consistent with the presence of a cyclonic eddy centered near Station I. Symmetrically, a deepening of the isotherms is observed close to the anticyclonic eddy, at the coastal Station D (Figure 5a) and at the offshore Station E (Figure 5b). The MLD along the offshore section is deeper in the cyclonic part west of the section (Stations I and K, $88 \mathrm{~m}$ deep on average) than in the anticyclonic part of the section (Stations B, $\mathrm{E}$, and $\mathrm{G}, 64 \mathrm{~m}$ on average).

It took approximately $17 \mathrm{hr}$ for the ship to sail from Station $\mathrm{D}$ to Station $\mathrm{K}$ where the dynamical processes of interest were observed. The bulge of high Chl-a associated with the cyclonic eddy was observed to be $\sim 50 \mathrm{~km}$ to the west 2 days before the satellite observation shown in Figure 3, and $\sim 80 \mathrm{~km}$ to the east 2 days after (not shown). This suggests a nonnegligible displacement velocity for this feature, of about 20 to $30 \mathrm{~cm} / \mathrm{s}$. As a result, the sampling of the dynamical structures from NF16 was not totally synoptic, and the structures detected on the cruise data might appear partially "compressed" zonally, as the cruise was going westward and these structures were going eastward. However, the cruise data allowed the clear identification of the 



Figure 5. (a) Vertical section along longitude $\left({ }^{\circ} \mathrm{W}\right)$ of temperature with contours $\left({ }^{\circ} \mathrm{C}\right)$ interpolated between temperature profiles from five CTD casts from NF16 at Stations J, H, F, D, and A, that is, along the coast (see Figure 3c), in the top $300 \mathrm{~m}$. (b) Same as (a) at Stations K, I, G, E, and B, that is, slightly offshore. (a, b) The solid gray line marks the mixed layer depth (see text for more details).

complex changes of current patterns, which took place on spatial scales shorter than the saw-like grid of the cruise track and which are consistent with the instantaneous satellite Chl-a image. In particular, the dimensions of the eddy structures were estimated based on portions of the ship track grid, as well as from the instantaneous satellite image. In addition, the meridional vertical transects (Figure 4) were each sampled within 2 to $3 \mathrm{hr}$ each, so that each of them is very close to a synoptic view.

We used additional in situ data, namely, SVP drifter data, to further investigate the mesoscale eddy dynamics along the northern coast of Cuba. SVP Drifter \#63704970 was deployed along the northern coast of Cuba, near Havana, on 20 August 2016 (Figure 6). In the first few days, the drifter went directly westward (Figure 6a), under northeasterly wind conditions (Figure 6j). These wind conditions became progressively favorable for upwelling as the coast orientation changed along the drifter trajectory, and, indeed, on 27 August the drifter started being entrained offshore along a filament of high Chl-a, which is typical of coastal upwelling (Figure 6a). In the following days, between 29 August and 3 September, intense southerly winds prevailed, which were due to the presence of a tropical depression that later formed Hurricane Hermine. Between 27 August and 3 September, the drifter was entrained offshore, before veering anticyclonically and returning southward toward the Cuban coast (Figure 6b). Surface Chl-a notably increased between both dates, due to the offshore entrainment of nutrient-rich, coastal waters, and the enhanced mixing due to the storm (Walker et al., 2005).

Starting on 4 September, the drifter started looping cyclonically. On 5 September (Figure 6c), northward filaments of high Chl-a waters were visible along the whole northern coast of Cuba, following the episode of intense southerly winds, and as intense easterly to northeasterly winds were present on 4 and 5 September (Figure 6j). On 14 and 17 September, the drifter was still looping inside the cyclonic eddy (Figures $6 \mathrm{~d}$ and $6 \mathrm{e}$ ). The winds were predominantly easterly to northeasterly between 5 and 17 September, except from 11 to 14 September when the winds turned to southerly (Figure 6j), and high Chl-a waters were visible on 14 and 17 September along the northern coast of Cuba (Figures 6d and 6e). After 14 September the winds returned to easterly or northeasterly, that is, upwelling favorable, until 4 October (Figure 6j). The drifter stayed inside the cyclonic eddy until 19 September, before being entrained southwestward along the coast (Figure 6f). The drifter was thus entrained during 15 days into a cyclonic eddy, and the dimension of the loops along the drifter trajectory suggests an eddy diameter of roughly 30 to $40 \mathrm{~km}$. This time period of $\sim 15$ days is remarkable, since the cyclonic eddy appeared to form locally, following wind-driven upwelling, and was expected to be short lived. Another remarkable aspect of this eddy is that it was associated with relatively low Chl-a signature. This might be due to the fact that large quantities of coastal waters were entrained offshore after the formation of the eddy around 4 September and could not be entrained into it, so that the Chl-a inside the eddy was lower than in surrounding waters.

Toward 30 September, the drifter trajectory deviated from following the direction of the coast and was entrained offshore, along a patch of high Chl-a waters, just north of the Gulf of Guanahacabibes (GG) near the Reserva Ecológica Los Pretiles (Figure 6f; see also Figure 1). In the following days, the drifter trajectory formed two small cyclonic loops as it was entrained eastward within the same patch of high Chl-a waters extending offshore, as seen on 3 October (Figure $6 \mathrm{~g}$ ), presumably due to coastal upwelling favored by 



0.04

0.1

$0.2 \mathrm{mg} / \mathrm{m}^{3}$



Figure 6. Surface Chl-a (colors, $\mathrm{mg} / \mathrm{m}^{3}$ ) derived from MODIS Aqua and Terra satellites, on (a) 27 August, (b) 3, (c) 5, (d) 14, (e) 17, and (f) 30 September, and (g) 3, (h) 5, and (i) 7 October 2016. Data for 14 September (d) were derived using the approach described by Chen et al. (2019, section 2). Superimposed in magenta is the trajectory of Surface Velocity Program (SVP) Drifter \#63704970 deployed on 20 August 2016 at the location marked by a magenta cross. The continuous magenta line indicates the last 15 days along the trajectory, and the position of the drifter at the date of each map is marked by a white dot. Black contours indicate the 200, 2,000, and 3,000 m isobaths. (j) Vectors of daily mean of winds, over the area marked by the white rectangle in (a), from ECMWF data (at sea locations only), from 1 August to 31 October 2016, with a reference arrow for $10 \mathrm{~m} / \mathrm{s}$ winds.

northeasterly winds (Figure 6j). Between 3 and 5 October, the drifter first kept a cyclonic trajectory and was entrained offshore to the north, following the same patch of high Chl-a waters, before it started to veer anticyclonically to the east (Figure 6h). After that date, the drifter was rapidly entrained to the east, following the Florida Current, as seen on 7 October (Figure 6i). The shape of the anticyclonic veering of the drifter on 5 October and the blue waters east of the patch of coastal, high Chl-a waters suggest the presence of an anticyclonic CubAN eddy, although the drifter did not sample this feature. 



Figure 7. (a) Surface Chl-a (colors, $\mathrm{mg} / \mathrm{m}^{3}$ ) observed by MODIS Terra on 16 May 2016. In red is the track of NF16. The black arrows are the velocity vectors measured by the onboard SADCP on the same day, averaged between 18 and $30 \mathrm{~m}$ depth. A reference arrow is included in the figure. (b) Same as (a), zoomed in the dashed white rectangle in (a). (c) Vertical section, in latitude $\left({ }^{\circ} \mathrm{N}\right)$, between Points $\mathrm{T}$ and $\mathrm{U}$, of the offshore currents measured by the onboard SADCP in the top $100 \mathrm{~m}$. The onboard SADCP experienced technical issues during the May 2016 cruise, which affected data acquisition and limited the amount of valid data. (d) Track of NF16 (red) with velocity vectors measured by the onboard SADCP, averaged between 18 and $30 \mathrm{~m}$ depth (black arrows). The sampling from Stations $\mathrm{O}$ to $\mathrm{T}$ (d) took approximately $14 \mathrm{hr}$. The names of the stations follow the chronological order of sampling. Point $\mathrm{U}$ does not correspond to an actual sampling station but was added to mark the end of the vertical section in (c). (a, b, d) Black contours indicate the 200 and $2,000 \mathrm{~m}$ isobaths.

The trajectory of this SVP drifter that was deployed in the fall of 2016 complements the observations from the NF16 cruise earlier in 2016, which sampled through a cyclonic eddy near an anticyclonic CubAN eddy. Indeed, the drifter trajectory showed how upwelling conditions, dominant during most of September 2016 along the northern Cuban coast, led to the formation of a cyclonic eddy just north of Cuba, whose dimensions are comparable to, though slightly larger than, the one observed during the NF16 sampling period and which lived about 15 days. Later, this same drifter was entrained offshore together with a patch of high Chl-a waters, again under upwelling-favorable wind conditions, and then veered anticyclonically around what we deduce to be a CubAN eddy, which is consistent with the observations that CubAN eddies and coastal upwelling are closely associated, as seen in the NF16 survey and diagnosed by Kourafalou et al. (2017).

\subsection{Western Tip of Cuba Region}

Later in May 2016, after sampling the deep southeastern GoM and along the Campeche Bank (see sections 3.4 and 3.5), NF16 headed back toward the western tip of Cuba. Near the Cuban coast, it took bottom topography measurements of the San Antonio Bank, near Cape San Antonio (at the end of the peninsula extending westward in Figure 7a), before collecting ocean observations along the GG (Figure 1) north of 
the peninsula on 16 May 2016 (Figure 7a). The GG is the large, shallow bay just north of Cape San Antonio, which hosts coral reef ecosystems (Alcolado et al., 2003). The ship followed a rectangular pattern over six stations, before returning south to the western tip of Cuba. Satellite observations on that day show the presence of small bulges of high Chl-a waters extending offshore along that portion of the shelf break. After completing the six stations (O to T), and while returning to Cape San Antonio to the south, the onboard SADCP sampled through the bulge of high Chl-a waters approximately at the same time as the satellite pass. Near-surface currents from the SADCP show an anticyclonic veering associated with this bulge (Figure 7b). On the vertical, the offshore currents were associated with a subsurface jet structure, centered at $55 \mathrm{~m}$ depth at the location of the tip of the bulge (Figure 7c). The offshore currents within the subsurface jet reached about $30 \mathrm{~cm} / \mathrm{s}$.

The near-surface currents, collected in the preceding hours along the rectangular track of the ship, also showed the signature of an anticyclonic feature near the shelf break between Stations $\mathrm{O}$ and $\mathrm{P}$ (Figure 7d), at a different location than the bulges seen on satellite observations. This suggests that these features evolve on short time scales, since the stations were typically collected only a couple of hours apart from one another. Currents on the offshore part of the rectangular pattern show a very intense northeastward current, associated with the LC flowing close to the Cuban coast at that period (see section 3.4 and Figure 10b). Because the dynamical features appear to be evolving rapidly during that period, the picture revealed by the acoustic Doppler current profiler (ADCP) near-surface currents along the rectangular grid between Stations $\mathrm{O}$ and $\mathrm{T}$ (Figure $7 \mathrm{~d}$ ) is probably not fully synoptic. However, we will consider currents along individual segments of the rectangular grid as synoptic, since this is the closest to synoptic that can be achieved with the onboard data. Currents between Stations Q and R show a marked slowdown of the northeastward flow close to the shelf break, also seen, to a lesser extent, between Stations S and T. This slowdown is expected from the friction between the LC and the continental shelf slope along the Cuban coasts. With the coast to the right of the current, the flow slowdown along the shelf break favors the increase in anticyclonic vorticity, similar to what is observed between the Gulf Stream and the shelf break off the Bahamas. Gula et al. (2016) indeed showed that negative vorticity on the anticyclonic (right) side of the Gulf Stream tends to intensify due to the topographic drag along the continental slope of the Bahamas islands. The same process may, indeed, explain the presence of anticyclonic features detected by the onboard SADCP along the continental shelf of the western tip of Cuba. Near-surface currents from the SADCP between Stations R and S also show anticyclonic veering of the flow, associated with offshore currents near Station $\mathrm{R}$, confirming the presence of anticyclonic circulation near the shelf break. The formation and presence of anticyclonic structures along the shelf break appear to be associated with the limited offshore transport of coastal waters as suggested by the satellite maps, since coastal waters usually have a larger amplitude in observed Chl-a than offshore waters. Unlike patterns observed along the northern coast of Cuba, the patterns of high Chl-a observed in May 2016 along the GG in northwest Cuba appear to be associated with anticyclonic circulation features.

The processes observed during NF16 took place as the LC was flowing northeastward and close to Cuba in a prolonged retracted position (see section 3.1). We had access to cruise data from other years in that area, under different LC conditions, which complement the NF16 findings.

We first analyzed the data collected during 2015 (NF15 cruise, Figure 8). At that time, the LC was well extended inside the GoM (Figure 8a). The near-surface currents from the onboard SADCP showed an anticyclonic circulation inside the base of the LC, also indicated by the isolines of MADT from altimetry (Figure 8a). Remotely sensed Chl-a from 21 May 2015 showed, inside the Yucatan Channel and along the GG, a filament of high Chl-a waters extending northwestward and following the edge of the LC. Looking more closely at the area near the western tip of Cuba, a large portion of the high Chl-a waters that formed the aforementioned filament seemed to originate from the shelf break along the GG (Figure 8b). The winds were indeed northeasterly, that is, upwelling favorable in that area, from 19 to 23 May 2015 (Figure 8e), supporting the offshore export of productive waters as observed on satellite Chl-a on 21 May (Figure 8b). Such a filament was also visible at about the same location on 23 May, at the date when the ship actually sampled through it, although the available satellite image was of lesser quality (Figure 8d). The near-surface currents measured with the onboard SADCP showed a cyclonic veering inside the filament of high Chl-a waters, next to the GG, whereas offshore currents followed the anticyclonic circulation of the LC (Figures 8b and 8d). On the vertical, the offshore currents within the filament were more intense near the surface down to $30 \mathrm{~m}$ 

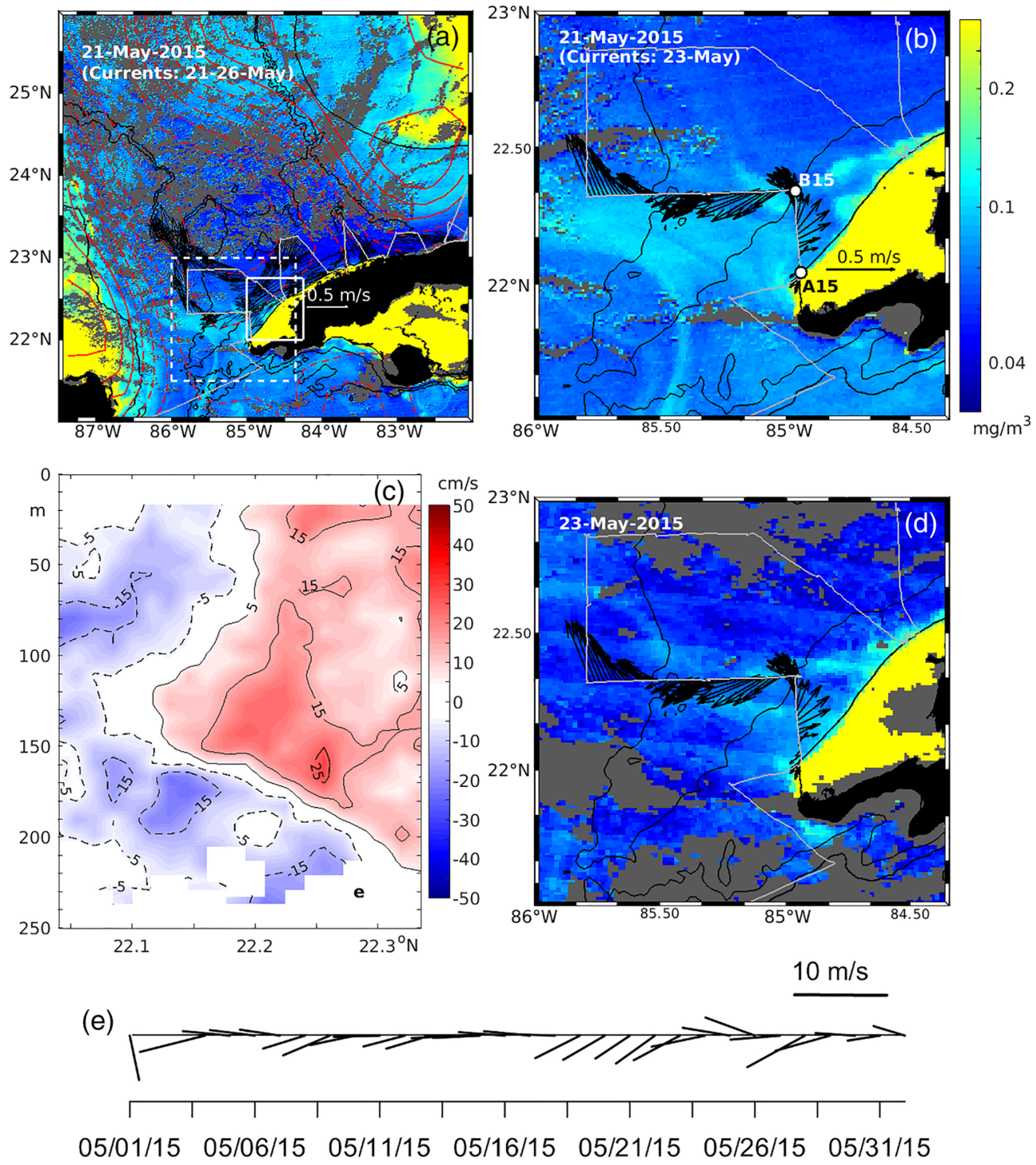

Figure 8. (a) Surface Chl-a (colors, $\mathrm{mg} / \mathrm{m}^{3}$ ) observed by MODIS Aqua on 21 May 2015. In gray is the track of the Nancy Foster during the 2015 cruise (NF15). Superimposed are the anomalies, on the same day, of the MADT with respect to the Gulf of Mexico spatial average (red contours every $10 \mathrm{~cm}$ ), derived from satellite altimetry. The positive anomalies of MADT are in dashed lines, the negative anomalies are in continuous lines. The black arrows are the velocity vectors measured by the onboard SADCP from 21 to 26 May 2015, between 16 and $18 \mathrm{~m}$ depth. A reference arrow is included in the figure. Black contours indicate the 200, 2,000, and 3,000 m isobaths. (b) Same as (a), without the MADT contours, zoomed in the area marked by the dashed white rectangle in (a). The black arrows are the velocity vectors measured by the onboard SADCP on 23 May 2015, between 16 and $18 \mathrm{~m}$ depth. (c) Vertical section, in latitude $\left({ }^{\circ} \mathrm{N}\right)$ between Points A15 and B15 (see (b) for their locations), of the offshore (northwestward) currents measured by the onboard SADCP in the top $250 \mathrm{~m}$. (d) Same as (b), but with the surface Chl-a (colors, $\mathrm{mg} / \mathrm{m}^{3}$ ) observed from MODIS Terra on 23 May 2015. (b, d) Black contours indicate the 200 and 2,000 m isobaths. (e) Vectors of daily mean of winds, over the area marked by the solid white rectangle in (a), from ECMWF data (at sea locations only), from 1 to 31 May 2015, with a reference arrow for $10 \mathrm{~m} / \mathrm{s}$.

depth, reaching $15 \mathrm{~cm} / \mathrm{s}$, as well as between 100 and $150 \mathrm{~m}$ depth, where the currents reached $15 \mathrm{~cm} / \mathrm{s}$ or more. Onshore currents were observed below $150 \mathrm{~m}$ depth, reaching $15 \mathrm{~cm} / \mathrm{s}$ locally (Figure $8 \mathrm{c}$ ), indicating the deep upwelling depth ( 150 m) over the western tip of Cuba under upwelling favorable winds.

In addition to the observations from the Nancy Foster, we also had access to the R/V Walton Smith data collected in the same area in May 2017 (WS17, Figure 9). At that time, the LC was extended to about $26^{\circ} \mathrm{N}$ (Figure 9a). We note that no LC eddy was actually shed between NF16 and WS17, as the LC did not start 

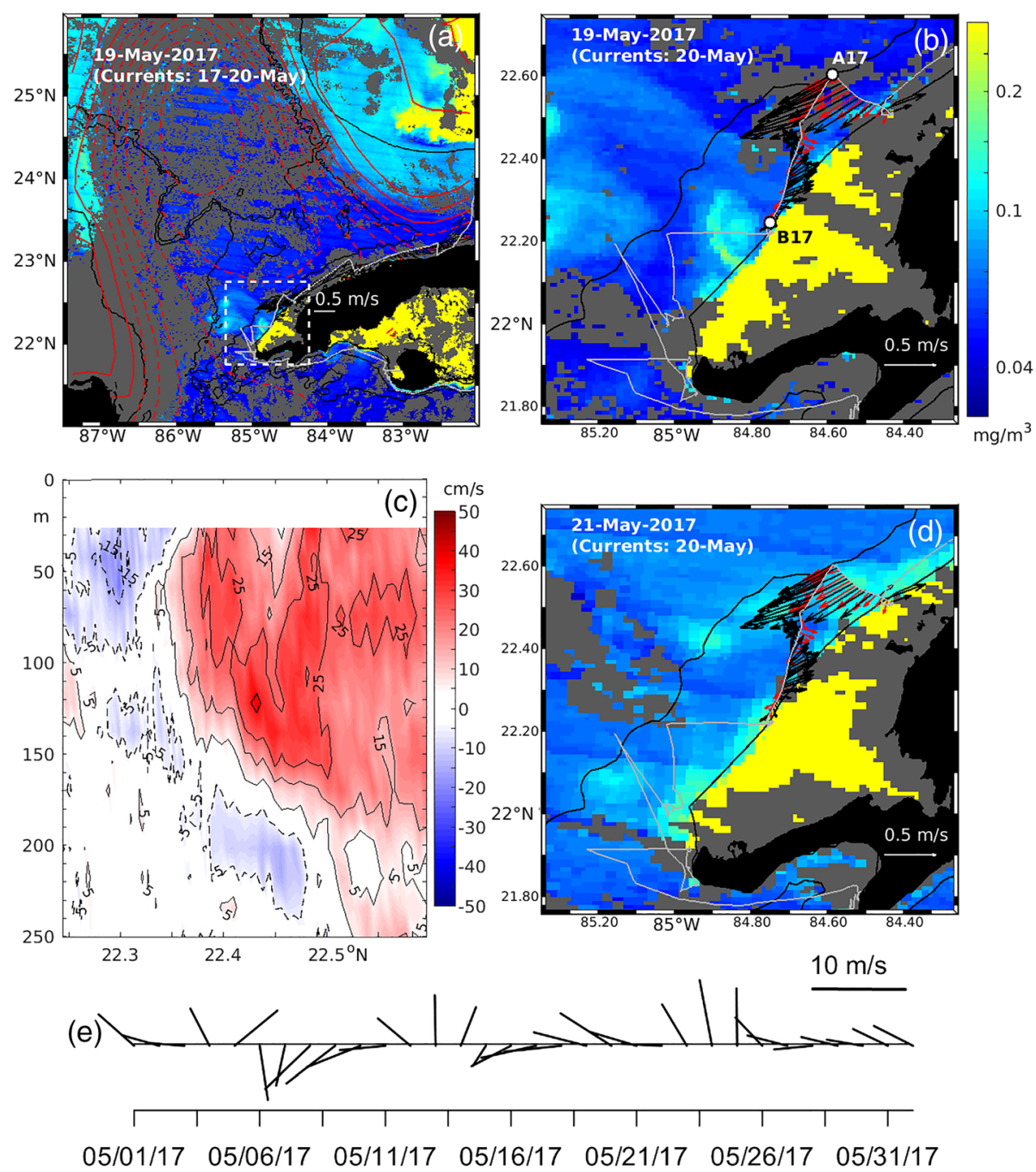

Figure 9. (a) Surface Chl-a (colors, $\mathrm{mg} / \mathrm{m}^{3}$ ) observed by MODIS Terra on 19 May 2017. In gray is the track of the R/V Walton Smith during the 2017 cruise (WS17). Superimposed are the anomalies, on the same day, of the MADT with respect to the Gulf of Mexico spatial average (red contours every $10 \mathrm{~cm}$ ), derived from satellite altimetry. The positive anomalies of MADT are in dashed lines; the negative anomalies are in continuous lines. The black arrows are the velocity vectors measured by the onboard SADCP from 17 to 20 May 2017 at $26 \mathrm{~m}$ depth. A reference arrow is included in the figure. Black contours indicate the 200, 2,000, and 3,000 m isobaths. (b) Same as (a), without the MADT contours, zoomed in the area marked by the dashed white rectangle in (a). The black arrows are the velocity vectors measured by the onboard SADCP on 20 May 2017 at $26 \mathrm{~m}$ depth. The additional red arrows are the velocity vectors measured by the onboard SADCP at $200 \mathrm{~m}$ depth on the same day. (c) Vertical section, in latitude ( ${ }^{\circ} \mathrm{N}$ ) between Points A17 and B17 (see (b) for their locations), of the offshore (northwestward) currents measured by the onboard SADCP in the top $250 \mathrm{~m}$. (d) Same as (b), but with surface Chl-a (colors, mg/m³) observed from MODIS Terra on 21 May 2017. (b, d) Black contours indicate the 200 and 2,000 m isobaths. (e) Vectors of daily mean of winds, over the area marked by the solid white rectangle in Figure 8a, from ECMWF data (at sea locations only), from 1 to 31 May 2017, with a reference arrow for $10 \mathrm{~m} / \mathrm{s}$.

extending until December 2016. As noted for the NF15 case, the near surface currents collected from the onboard SADCP showed an anticyclonic circulation inside the base of the LC, in agreement with the MADT isolines. Similar to 2015 also, the area near the GG is marked with offshore filaments of high Chl-a waters (Figure 9a). The winds were again northeasterly, that is, upwelling favorable, on 15-16 May, before gradually turning to easterly on 17-18 May and southeasterly on 19-21 May (Figure 9e). The two satellite Chl-a images available were taken on 19 and 21 May (Figures 9a, 9b, and 9d), whereas the onboard SADCP data from WS17 were collected on 20 May. Between those 2 days the northern extent of the high Chl-a waters seemed to slightly shift northward, maybe due to the change in the wind direction (Figure 9e). This limited shift suggests that the R/V Walton Smith was able to sample inside the high Chl-a waters. The near-surface currents from the onboard SADCP showed a cyclonic veering inside the offshore filament of high Chl-a waters that is similar to the one observed during NF15. The vertical 



0.04

0.1

0.2

$0.4 \mathrm{mg} / \mathrm{m}^{3}$

Figure 10. Surface Chl-a (colors, $\mathrm{mg} / \mathrm{m}^{3}$ ) observed from MODIS Aqua and Terra satellites, on (a) 7, (b) 14, (c) 21 , and (d) 28 May, (e) 24 June, (f) 10 and (g) 26 July, and (h) 2 and (i) 11 August 2016. The NF16 track is marked with a white line, from 10 to 14 May and from 14 to 19 May in (b) and (c), respectively, together with the location of Stations L, M, and N that mark the sampling of a Loop Current frontal eddy (CTD casts were sampled between Stations L and M, and between Stations M and N, but were not attributed a station letter). The trajectory of SVP Drifter \#139947 is marked in green, while the trajectory of Drifter \#139942 is marked in yellow. Both drifters were deployed at locations marked by crosses from NF16 on 13 and 14 May, respectively. The continuous line indicates the last 30 days along each trajectory, and the white dots indicate the position of each drifter at the date of each map. Superimposed are the anomalies, on the corresponding dates, of the MADT with respect to the Gulf of Mexico spatial average on the same day (red contours every $10 \mathrm{~cm}$ ), derived from satellite altimetry. The positive anomalies of MADT are in dashed lines; the negative anomalies are in continuous lines. Through geostrophy, closed dashed contours are associated with anticyclonic eddies, and closed continuous contours are associated with cyclonic eddies. Black contours indicate the 200, 2,000, and 3,000 $\mathrm{m}$ isobaths.

structure of the offshore currents (Figure 9c) is also comparable to the one observed in 2015: offshore currents in the top $150 \mathrm{~m}$, although more intense than in 2015 with large portions over $25 \mathrm{~cm} / \mathrm{s}$, and onshore currents below $150 \mathrm{~m}$ depth, although less intense than in 2015, between 5 and $10 \mathrm{~cm} / \mathrm{s}$. The most intense onshore currents were found near $200 \mathrm{~m}$ depth, and their location is shown in Figures $9 \mathrm{~b}$ and $9 \mathrm{~d}$. Despite some differences in amplitude, the overall structure of the offshore filaments was similar in 2015 and 2017. 
The NF15 and WS17 in situ observations provide some perspective on the NF16 data collected along the GG. It appears that the presence of small-scale anticyclonic circulation features, associated with limited offshore transport of high Chl-a waters, as in May 2016 (Figure 7), is associated with the LC being retracted and flowing close to the Cuban coast north of the Yucatan Channel. At times when the LC is well extended inside the GoM, as observed in May 2015 and May 2017, offshore filaments of high Chl-a waters, supported by upwelling favorable wind conditions, are marked with cyclonic circulation. In the vertical, they are marked with offshore currents in the top $150 \mathrm{~m}$ of the ocean and onshore currents below. More importantly, as revealed by satellite Chl-a images, these filaments can be entrained far offshore along the anticyclonic circulation of the LC (e.g., Figures 8a and 9a). The Chl-a image on 21 May 2015 (Figure 8a), in particular, shows how a filament of high Chl-a, which partially originated from the GG, was entrained westward and reached the portion of the LC that just entered inside the GoM.

\subsection{LCFE}

Between the sampling of the northwestern Cuban coast and the sampling of western tip of Cuba, NF16 sampled the large LCFE that formed in the weeks preceding the cruise (see section 3.1). From 12 to 15 May, the sampling followed this eddy westward at $24^{\circ} \mathrm{N}$, from $84^{\circ} \mathrm{W}$ to $86^{\circ} \mathrm{W}$, then southward along $86^{\circ} \mathrm{W}$ from $24^{\circ} \mathrm{N}$ to $22^{\circ} \mathrm{N}$ (Figures $10 \mathrm{~b}$ and 10c). On 13 and 14 May, three SVP drifters were deployed inside the LCFE, two at approximately $24^{\circ} \mathrm{N}, 86^{\circ} \mathrm{W}$ on 13 May (ID \#139946 and \#139947) and one at approximately $23.5^{\circ} \mathrm{N}, 86^{\circ} \mathrm{W}$ on May 14 (ID \#139942). Figure 10 depicts the evolution of the large LCFE from early May to early August 2016, based on satellite Chl-a and MADT estimates, as well as the trajectories of Drifters \#139942 and \#139947 (Drifter \#139946 was quickly ejected from the LCFE after only one loop).

On 7 May, the LCFE was still centered at $\sim 23.5^{\circ} \mathrm{N}, 86^{\circ} \mathrm{W}$, as it had been on 5 May (Figure 2d). However, whereas on 5 May small, isolated patches of high Chl-a were following the northern edge of the LC from the Campeche Bank eastward toward the Straits of Florida, on 7 May similar patches followed the edge of the newly formed LCFE and turned cyclonically around it (Figure 10a). At the entrance of the GoM, just north of the Yucatan Channel, the LC was pushed to the east by the large LCFE and flowed from the southwest to the northeast along the northwestern tip of Cuba. It then formed a northward bulge along the edge of the West Florida Shelf, before entering the Straits of Florida. On 14, 21, and 28 May, the LC was still forced to flow along the northwestern tip of Cuba just north of the Yucatan Channel, but its extension along the West Florida Shelf was limited by the eastward extension of the LCFE (Figures 10b, 10c, and 10d). This is visible in the Chl-a field, showing the LCFE extending to the northeast, marked with larger Chl-a than the waters within the LC to the south or the waters within the LC eddy to the north (centered at $\sim 26^{\circ} \mathrm{N}, 87^{\circ} \mathrm{W}$ ). This is also visible in the altimetry data, with the shape of the closed contours of MADT associated with a MADT minimum and hence a cyclonic eddy. It is also visible in the trajectories of the SVP drifters deployed inside the LCFE, which followed an elliptic, cyclonic path that extended toward the northeast between their deployment and 28 May.

Between 28 May and 24 June, the cloud coverage prevented the observation of the surface Chl-a in the eastern GoM. However, during that period SVP Drifter \#139947 deployed on 13 May (in green in Figure 10) followed another elliptic, cyclonic path, before being advected onto the West Florida Shelf, while Drifter \#139942, deployed on 14 May (in yellow in Figure 10), followed elliptic, cyclonic loops closer to the center of the LCFE and still appeared to be inside the eddy on 24 June (Figure 10e). At that date, the shape of the LCFE evolved to a bent ellipse, and its approximate center (near $24^{\circ} \mathrm{N}, 86^{\circ} \mathrm{W}$ ) slightly moved to the northwest compared to May. The LCFE's surface signature decreased, in both its dimension and the number of closed MADT contours characterizing it: The eddy was less extended to the east than in late May and was associated with only two closed MADT contours on 24 June, whereas it was associated with four to five closed MADT contours in early May. Between the end of May and the end of June, as the LCFE size decreased and its center moved slightly to the northwest, the LC at the entrance of the GoM did not flow as close to the northwestern tip of Cuba as it did in early May.

In July and August, the shape of the LCFE kept changing significantly. In July, the core of the eddy appeared to be located near $23.6^{\circ} \mathrm{N}, 86.2^{\circ} \mathrm{W}$, but the eddy seemed to expand to the northeast again (Figures $10 \mathrm{f}$ and 10g). Drifter \#139947 (in green), which was advected onto the West Florida Shelf in June, was entrained back onto the deep GoM and followed the outer edge of the cyclonic LCFE to the west. Meanwhile, Drifter \#139942 (in yellow) kept following cyclonic, elliptic loops near the LCFE core (Figures 10f and 



Figure 11. (a) Drifter trajectory (black line) in distance frame $\left(\mathrm{km}\right.$, centered at $\left.86^{\circ} \mathrm{W}, 24^{\circ} \mathrm{N}\right)$, with the location, in color, of the points for which the analysis tool identified a looping trajectory, from 5 June to 14 July 2016 (see text for more details). The corresponding time-varying ellipses are in magenta. (b) Drifter velocity $V(\mathrm{~cm} / \mathrm{s})$ along the looping trajectory (positive values for counterclockwise rotation), with the corresponding radius $R(\mathrm{~km})$. The relative vorticity along the looping trajectory under the hypothesis of solid-body rotation is indicated.

10g). The LC, although not constrained to flow along the northwestern tip of Cuba as in May, was still blocked from extending northward by the presence of the LCFE. In August, the core at the western part of the LCFE, where it had been located since the eddy formation in April and May, began to vanish. At the same time a second core within the same cyclonic structure, much more to the northeast at around $24.8^{\circ} \mathrm{N}, 85.5^{\circ} \mathrm{W}$, seemed to grow in size and amplitude, as suggested by the MADT contours on 2 and 11 August (Figures 10h and 10i). Drifter \#139942 (in yellow), which had been following cyclonic loops inside the LCFE since May, stopped looping between the end of July and early August, before being advected northward along the edge of the new core of the LCFE. After that date, the core of the LCFE was not sampled by any drifter. However, the LC stayed retracted until the end of November 2016, after 7 months of very marked southward position, before starting to grow again (not shown). This makes the second half of 2016 a remarkable period, as the LC remained abnormally retracted for months.

The drifter trajectories described in Figure 10 were used to extract additional information about the large LCFE sampled by NF16. Figure 11 shows the analysis of the trajectory of Drifter \#139942 (in yellow in Figure 10), which was entrained inside the LCFE for weeks. Following Le Hénaff et al. (2014), we used the drifter trajectory analysis tool developed by Lilly et al. (2011), which allows characterizing the looping component of a drifter trajectory that corresponds to eddy entrainment. Figure 11b shows the estimate of the eddy radius and the looping velocity along the eddy ellipse, at points identified in Figure 11a. After an initial stage of the trajectory, until approximately 20 June, in which the radius decreased while the velocity increased, the radius and looping velocity estimates formed a straight line. This is typical of solid body rotation (Le Hénaff et al., 2014; Lilly \& Rhines, 2002), which was already found for another LCFE in the southeastern GoM in 2004 (Le Hénaff et al., 2014). Here, the relative vorticity corresponding to the slope between the radius and rotation velocity estimates is equal to $0.19 f, f$ being the local Coriolis frequency, which is lower than most LCFEs (Le Hénaff et al., 2014). The LCFE sampled in 2004 initially had a relative vorticity of $0.69 f\left(4.2 \times 10^{-5} \mathrm{~s}^{-1}\right)$, which dropped to $0.28 f\left(1.7 \times 10^{-5} \mathrm{~s}^{-1}\right)$ after what appeared to be a rearrangement of the eddy. It is not clear if the low relative vorticity value observed in the LCFE sampled in 2016 is due to the merging of two LCFEs that led to the LC eddy shedding (see section 3.1) or if it is due to a subsequent rearrangement of the eddy, as was observed in 2004 (Le Hénaff et al., 2014). Further studies are necessary to better understand the processes affecting vorticity within LCFEs in the southeastern GoM, as these might have an impact on the LC system.

Figure 10 suggests that the large LCFE experienced significant changes in its shape shortly after its formation at the end of April and early May of 2016, from an initial circular shape to a more elongated shape. The survey was able to sample the LCFE in its early stages, when it was close to circular (Figure 10b). Figure 12 shows the vertical sections of temperature and salinity taken across the LCFE, first from east to west at $24^{\circ} \mathrm{N}$, between Stations $\mathrm{L}$ and $\mathrm{M}$, then from north to south at $86^{\circ} \mathrm{W}$, between Stations $\mathrm{M}$ and $\mathrm{N}$. Nine CTD casts were also sampled between Stations L and M, and six casts between Stations M and N, but were not attributed a station letter. The panels for temperature (Figures 12a and 12b) and salinity 


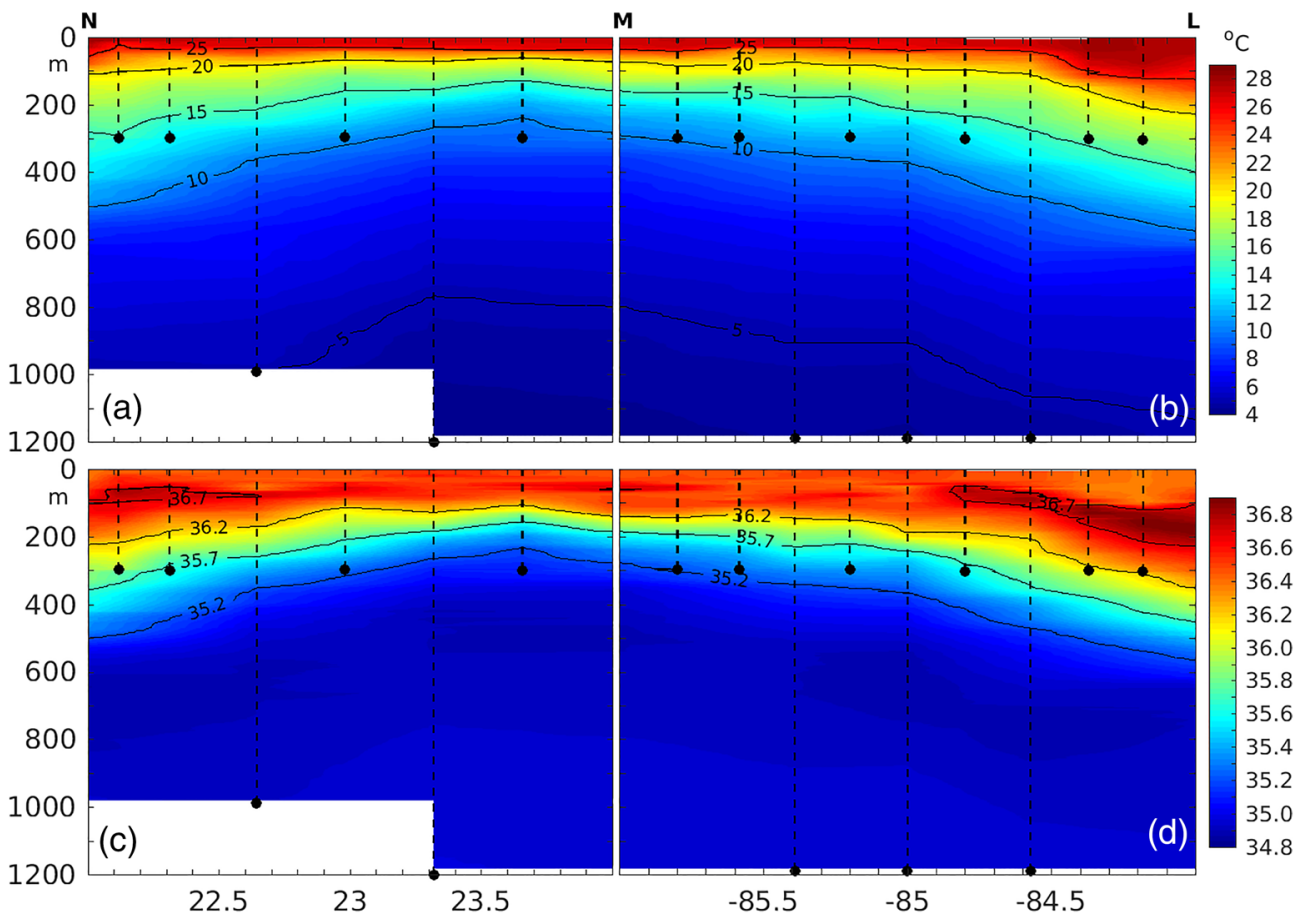

Figure 12. (a) Vertical section of temperature in latitude $\left({ }^{\circ} \mathrm{N}\right)$ at $86^{\circ} \mathrm{W}$ between Stations $\mathrm{N}$ and $\mathrm{M}$ (see Figure 10), interpolated from CTD casts collected on NF16, from the surface to $1,200 \mathrm{~m}$ depth. (b) Same as (a) but in longitude at $24^{\circ} \mathrm{N}$, between Stations M and L. (c, d) Same as (a) and (b) for salinity. CTD casts were sampled between Stations L and M, and between Stations M and N, but were not attributed a station letter. (a-d) Each CTD cast is indicated by a vertical dashed black line, with a black circle at the deepest measurement. The CTD casts at Stations L, M, and N extended to 1,200 m depth.

(Figures 12c and 12d) follow a conventional presentation of the sections with, from left to right, the zonal (positive northward) direction then the meridional (positive eastward direction). One in two or three CTD casts covered the water column down to 1,200 $\mathrm{m}$ depth, while the other ones went down to $300 \mathrm{~m}$ depth. Both temperature and salinity sections show the typical water masses found in the GoM. First, the LC, sampled at the southern and eastern ends of the sections, is marked with a deep thermocline. LC waters also typically present an underwater salinity maximum, between 100 and $200 \mathrm{~m}$ at the core of the LC in the eastern end of the zonal section (Figure 12d), which can be also seen at the edge of the LC at the southern end of the meridional section, at a slightly shallower depth above $100 \mathrm{~m}$ (Figure 12c). This salinity maximum reaches 36.8 and is the signature of Subtropical Underwater, which is typical of the Caribbean Sea and enters the GoM via the Yucatan Channel (Gordon, 1967). By contrast, the LCFE, which occupies the central part of the sections, is composed of Gulf Common Waters, with a shallow thermocline and no underwater salinity maximum.

Both temperature and salinity sections in Figure 12 show the shoaling, at the core of the LCFE, of isotherms and isohalines, associated with the upwelling inside a cyclonic eddy. The approximate center of the eddy was located between $23.3^{\circ} \mathrm{N}$ and $24^{\circ} \mathrm{N}$, along the meridional section at $86^{\circ} \mathrm{W}$. What is remarkable here is that this shoaling was observed down to $1,200 \mathrm{~m}$, whereas previous sections through a LCFE did not go deeper than $1,000 \mathrm{~m}$ (Vukovich \& Maul, 1985). This confirms previous observations, from mooring time series, of a signature of LCFEs at depth (1,500 m; Androulidakis et al., 2014), and this suggests that LCFEs can extend deeper than the depth of the LC (800 to 1,000 m; e.g., Lugo-Fernandez \& Leben, 2010; Welsh et al., 2009), which has implications for the understanding of the LC system.

\subsection{Campeche Bank Region}

Just south of the LCFE, NF16 sampled into a filament of high Chl-a waters extending from the Campeche Bank (Figures 10b and 10c). Vertical profiles of relative chlorophyll a were also collected during the cruise, in addition to temperature and salinity. Figure 13 shows the sections of relative chlorophyll a along the zonal and meridional sections across the LCFE, as well as temperature, in the top $150 \mathrm{~m}$. The temperature section (Figures 13a and 13b) shows the upper part of the ocean structure seen in Figure 12, with the LC on the 


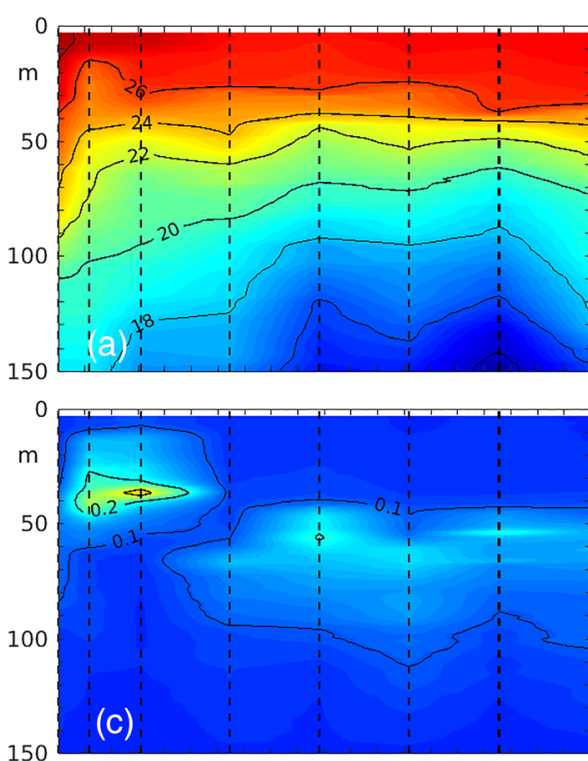

150

$$
22.5
$$

23 $23.5^{\circ} \mathrm{N}$
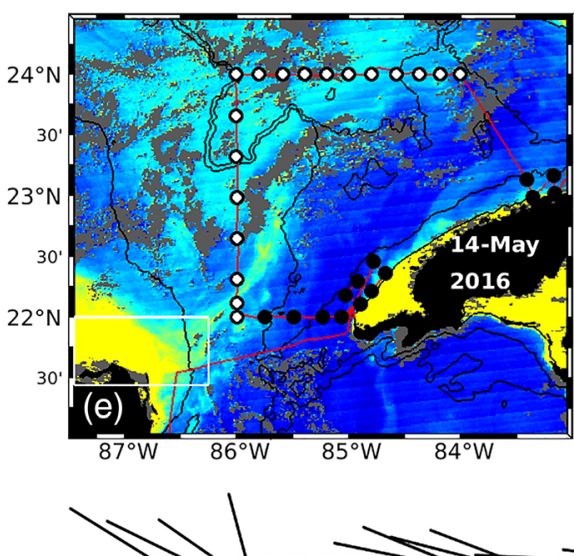

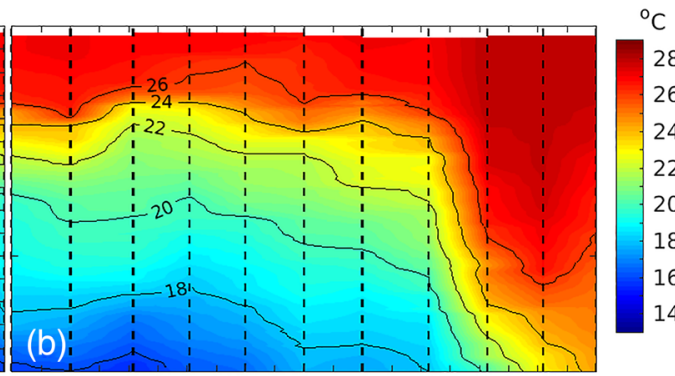

${ }^{\circ} \mathrm{C}$

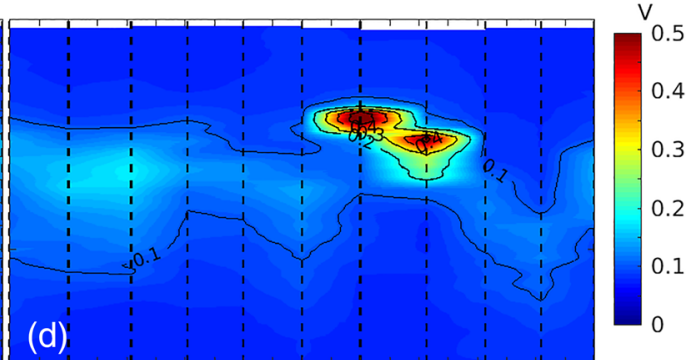

85.5

85 $84.5^{\circ} \mathrm{W}$

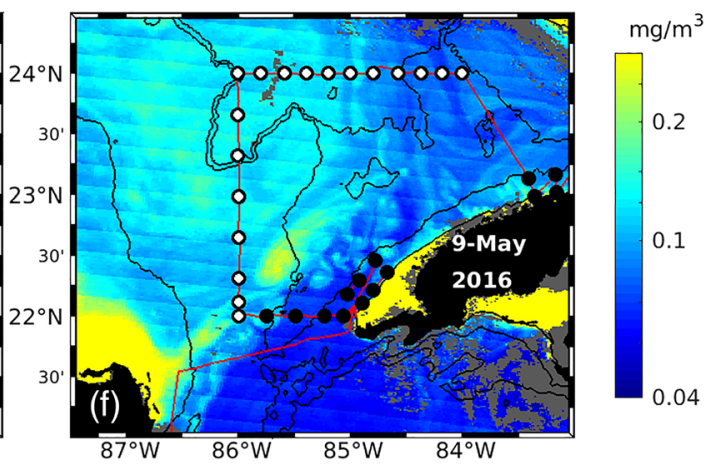

(g)

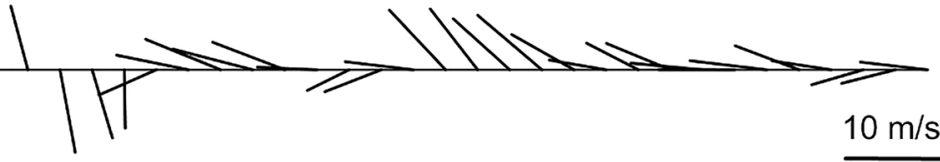

$10 \mathrm{~m} / \mathrm{s}$

\section{5/01/16 $\quad 05 / 06 / 16 \quad 05 / 11 / 16 \quad 05 / 16 / 16 \quad 05 / 21 / 16 \quad 05 / 26 / 16 \quad 05 / 31 / 16$}

Figure 13. (a) Vertical section of temperature $\left({ }^{\circ} \mathrm{C}\right)$ in latitude $\left({ }^{\circ} \mathrm{N}\right)$ at $86^{\circ} \mathrm{W}$, between Stations $\mathrm{N}$ and $\mathrm{M}$, interpolated from CTD casts collected by NF16, from the surface to $150 \mathrm{~m}$. (b) Same as (a) but in longitude ( ${ }^{\circ} \mathrm{W}$ ) at $24^{\circ} \mathrm{N}$, between Stations M and L. (c, d) Same as (a) and (b) for relative chlorophyll a (volts, V). (a-d) Each CTD cast is indicated by a vertical dashed black line. (e, f) Surface Chl-a (colors, $\mathrm{mg} / \mathrm{m}^{3}$ ) observed from MODIS Aqua and Terra satellites, on 14 and 9 May 2016, respectively. The locations of the CTD casts collected during the cruises are marked with circles; the white circles are the CTD casts used to derive the vertical sections. Black contours indicate the 200, 2,000, and 3,000 $\mathrm{m}$ isobaths. (g) Vectors of daily mean of winds over the area marked by the white rectangle in (e) from ECMWF data (at sea locations only), with a reference arrow for $10 \mathrm{~m} / \mathrm{s}$.

southern and eastern ends of the sections, marked with a deep thermocline, and the LCFE in the center marked with a shallow thermocline. The relative chlorophyll a section shows, in addition to the deep chlorophyll maximum (DCM) between 50 and $70 \mathrm{~m}$ with values of 0.1 to $0.15 \mathrm{~V}$, patches of much higher relative chlorophyll a at 30 to $40 \mathrm{~m}$ depth between $22.1^{\circ} \mathrm{N}$ and $22.4^{\circ} \mathrm{N}$ and at 40 to $60 \mathrm{~m}$ depth between $84.5^{\circ} \mathrm{W}$ and $85^{\circ} \mathrm{W}$ (Figures $13 \mathrm{c}$ and $13 \mathrm{~d}$ ). In these patches, the relative chlorophyll a reached 0.3 to $0.5 \mathrm{~V}$, more than twice the DCM values in the surrounding waters.

Figures $13 \mathrm{e}$ and $13 \mathrm{f}$ show the surface Chl-a estimated from satellite, at dates close to the collection of the CTD casts presented above. The southern part of the meridional section at $86^{\circ} \mathrm{W}$, where one of the 
patches of high underwater chlorophyll a was collected, was sampled on 14 May. On the same day, we see a large filament of coastal waters from the Campeche Bank being advected along the LC toward the northeast (Figure 13e). The patch of large underwater chlorophyll a at $22.1-22.4^{\circ} \mathrm{N}$ was sampled when the ship track intersected this tongue of coastal waters. The patches of large underwater chlorophyll a between $84.5^{\circ} \mathrm{W}$ and $85^{\circ} \mathrm{W}$ were collected earlier during the cruise, on 12 May. Due to cloud coverage, there is no surface Chl-a image available from satellite ocean color measurements on that date. However, a map of Chl-a collected on 9 May shows the presence, along the LC, of a large patch of high Chl-a at the surface, at about $22.4^{\circ} \mathrm{N}$, $85.6^{\circ} \mathrm{W}$, which also appeared to originate from the Campeche Bank (Figure 13f). That patch was advected along the LC and likely intersected the ship track a couple of days later. Although there is no satellite observation to confirm this hypothesis, it is thus possible that the CTD casts conducted by the ship sampled the water column inside that patch of shelf waters from the Campeche Bank. In any case, the underwater chlorophyll a maxima observed between $84.5^{\circ} \mathrm{W}$ and $85^{\circ} \mathrm{W}$ were comparable with the underwater chlorophyll a maximum observed between $23.1^{\circ} \mathrm{N}$ and $23.4^{\circ} \mathrm{N}$ under a filament of shelf waters originating from the Campeche Bank. In addition, these maxima were observed at the edge of the LC, where the filaments originating from the Campeche Bank were advected. This suggests that the export of shelf waters from the Campeche Bank to the deep GoM, and potentially to the Straits of Florida, which was characterized from satellite Chl-a by Otis et al. (2019), is associated with the presence of a chlorophyll a maximum between 30 and $60 \mathrm{~m}$ depth, that is, in the subsurface.

Wind data from ECMWF show that the winds over the eastern portion of the Campeche Bank were predominantly easterly between 8 and 16 May (Figure 13g), which is favorable for coastal upwelling along the northern coast of the Yucatan Peninsula and thus for offshore transport of coastal waters. The Campeche Bank is known as an upwelling regime, precisely because winds are predominantly easterly in the region (Zavala-Hidalgo, Gallegos-García, et al., 2006). These upwelled waters can participate in the intensification of cyclonic eddies forming along the shelf (Androulidakis et al., 2014). In addition, the LC flowing along the eastern edge of the Campeche Bank favors the offshore transport of shelf waters, as illustrated by Otis et al. (2019), which is also seen in Figures $13 \mathrm{e}$ and $13 \mathrm{f}$ with the filaments of shelf waters following the LC far into the deep GoM. The export of waters with large chlorophyll a signature at 30-60 m depth, as was observed during NF16, might thus be a frequent pattern, although these subsurface peaks cannot be observed by satellite. Further research will be necessary to estimate the potential impacts of these subsurface, high chlorophyll filaments, on the GoM biology and ecosystems.

\section{Summary and Concluding Remarks}

We used a unique data set, with recent in situ data in the Cuban waters within the GoM collected by the NOAA Ship Nancy Foster in May 2016 (NF16), in tandem with other available cruise data collected over the same area in May 2015 and in May 2017 (NF15 and WS17, respectively). These data are valuable, both for enriching the undersampled region of the southeastern GoM and for revealing important processes of cross-shelf transport in this dynamically complex area.

First, along the northern coast of Cuba, NF16 provided the first in situ measurements of a CubAN eddy of $\sim 50 \mathrm{~km}$ diameter, which was observed together with wind-driven coastal upwelling and the associated offshore transport of productive upwelled waters that recirculated inside a cyclonic eddy of $\sim 25 \mathrm{~km}$ diameter. Both eddy structures had signature in the top $300 \mathrm{~m}$, where the observations were taken: The cyclonic eddy was associated with a shoaling of isotherms (upwelling), while the CubAN eddy was associated with a deepening of the isotherms (downwelling). Later in August of 2016, a surface drifter was trapped inside a comparable cyclonic eddy, with a slightly larger diameter of 30 to $40 \mathrm{~km}$, which was observed for $\sim 15$ days during upwelling favorable wind conditions. A few days later, the same drifter was entrained offshore once more, further west along the northern coast of Cuba near the Reserva Ecológica Los Pretiles (Figure 1), together with another upwelling filament. These observations suggest that coastal upwelling filaments are common along the northern coast of Cuba, confirming visual inspection of satellite ocean color images. In addition to bringing colder, more productive waters to the surface, these upwelling filaments form pathways for offshore transport at the ocean surface. In that region of potential oil exploration (and also oil vessel marine traffic), they might export oil offshore in case of a spill. They can also export fish or coral larvae from local nearshore ecosystems toward the interior of the Straits of Florida, for example, from the Reserva Ecológica Los Pretiles, 
which is an MPA. On the other hand, mesoscale eddies, both anticyclonic (CubAN) and cyclonic, might retain exported material, as observed for the drifter that was trapped inside a cyclonic eddy.

Second, along the western tip of Cuba, coastal upwelling also offers a way to export coastal waters far offshore into the LC system. This is also of interest for ecosystem studies in the GoM, since the western tip of Cuba hosts a major Cuban MPA, the Parque Nacional Península de Guanahacabibes, and is near the Reserva Ecológica Los Pretiles. Material such as larvae, produced in these MPAs, potentially has a northwestern route to the GoM interior via these offshore upwelling filaments, when the LC is extended, as was the case in 2015 and 2017. Similarly, this pathway can be followed by oil at the ocean surface, in case of an oil spill. On the other hand, when the LC is retracted, as was the case in 2016, the offshore transport along Cuba is limited; however, the proximity of the LC makes it possible to transport material directly toward the Straits of Florida.

Finally, near the Campeche Bank, along the southern edge of a very large cyclonic LCFE that was formed in April-May 2016, NF16 data allowed us to describe, for the first time, the vertical structure of filaments of coastal waters exported from the Campeche Bank toward the GoM interior and the Straits of Florida. These filaments, which are characterized by high surface Chl-a visible from satellite (e.g., Otis et al., 2019), were associated with intense peaks in relative chlorophyll a at depths ranging from 30 to $60 \mathrm{~m}$ that were much more intense than the surrounding DCM values. It is not clear how these peaks formed, and further studies are necessary to understand and quantify this process.

The cases of offshore transport illustrate how coastal circulation along the northwestern coast of Cuba and along Mexico's Campeche Bank can be involved in offshore transport processes. Along the western tip of Cuba, these transport processes appear directly modulated by the extension of the LC, whereas this influence might not be as direct along the northern coast of Cuba, since it is further away from the LC. However, since the frequency of CubAN eddy formation is modulated by the extension of the LC, as shown by Kourafalou et al. (2017), the LC extension appears likely to also influence the offshore transport processes in that area.

In addition to these coastal processes, NF16 also sampled through a remarkably large cyclonic LCFE that formed during the shedding process of an LC eddy. This LCFE had a diameter of $\sim 250 \mathrm{~km}$, that is, more than twice the 80 to $120 \mathrm{~km}$ diameter usually observed for LCFEs (Le Hénaff et al., 2014; Vukovich \& Maul, 1985). This LCFE had an unusual position close to the Campeche Bank, further south than the large LCFEs that are usually observed north of the retracted LC (Le Hénaff et al., 2014; Zavala-Hidalgo, Morey, et al., 2006; Zavala-Hidalgo et al., 2002). As a result, the LC was kept close to the northwestern coast of Cuba, just north of the Yucatan Channel, rather than following a northward path along the Campeche Bank. This LCFE was sampled by near-surface drifters, which revealed that the LCFE reached solid-body rotation in June-July 2016. This confirms previous observations, in 2004, of an LCFE in solid body rotation (Le Hénaff et al., 2014). The LCFE sampled in May 2016 had a relative vorticity of $0.19 f$, which is lower than most LCFEs (Le Hénaff et al., 2014). The vertical section of temperature derived from the NF16 data set showed that the signature of the LCFE extended down to at least 1,200 $\mathrm{m}$ (the deepest observations collected). This confirms results from Androulidakis et al. (2014) and means that LCFEs can have a deeper signature than the LC itself (800-1,000 m), which has implications for understanding the dynamics of the LC system.

Our study has advanced the understanding of coastal to offshore interactions in the southeastern GoM. Our findings illustrate how coastal processes, in particular, coastal upwelling and mesoscale cyclonic and anticyclonic (CubAN) eddies, have to be taken into account when studying, modeling, and forecasting material transport in northern Cuba waters and the broader southeastern GoM, for oil pollution or biological population connectivity studies. These processes are closely related to wind conditions along the coasts of Cuba, which have to be well represented in atmospheric modeling and forecasting. In addition, since these processes are intrinsically connected to the LC system (i.e., LC, LC eddy, and associated LCFEs), it is crucial to also take into account the regional, basin-wide circulation in the GoM when investigating their local impacts.

\section{Data Availability Statement}

The in situ data are publicly available on the NOAA National Centers for Environmental Information (NCEI) portal (https://www.ncei.noaa.gov/), in the Oceans data set. Diagnostics derived from the in situ observations are publicly available through the Gulf of Mexico Research Initiative Information \& Data 
Cooperative (GRIIDC; doi: 10.7266/n7-3vmj-nk86). Wind data were derived from the European Centre for Medium-Range Weather Forecasts (https://www.ecmwf.int). The MODIS data are openly accessible from NASA (https://oceancolor.gsfc.nasa.gov/).

\section{Acknowledgments}

This research was made possible in part by a grant from The Gulf of Mexico Research Initiative (\# G-231819) and in part by the National Academy of Sciences, Engineering and Medicine (Gulf Research Program UGOS \#2000011056). Additionally, M. Le Hénaff received partial support for work on this publication by NOAA/AOML and was supported in part under the auspices of the Cooperative Institute for Marine and Atmospheric Studies (CIMAS), a cooperative institute of the University of Miami and NOAA, cooperative agreement NA10OAR4320143. Data collection efforts and postcruise data analysis were made possible by support from NOAA Atlantic Oceanographic and Meteorological Laboratory and NOAA Southeast Fisheries Science Center, together with funding support from NMFS Fisheries And The Environment (FATE) and from the NASA Biodiversity and Ecological Forecasting program. This study has been conducted using E.U. Copernicus Marine Service Information. The ocean chlorophyll a concentration images were developed in the Optical Oceanography Laboratory (University of South Florida), based on the MODIS data. We thank L. Johns for useful suggestions that improved the manuscript. We thank two anonymous reviewers for their very helpful suggestions. The authors wish to thank the crews of the NOAA Ship Nancy Foster, and of the University of Miami's R/V F.G. Walton Smith, for their efforts in the collection of the shipboard data sets presented.

\section{References}

Alcolado, P. M., Claro-Madruga, R., Menéndez-Macías, G., García-Parrado, P., Martínez-Daranas, B., \& Sosa, M. (2003). The Cuban coral reefs. In J. Cortés (Ed.), Latin American coral reefs (pp. 53-75). Amsterdam: Elsevier Science.

Androulidakis, Y., Kourafalou, V. H., Le Hénaff, M., Kang, H.-S., Sutton, T., Chen, S., et al. (2019). Offshore spreading of Mississippi waters: Pathways and vertical structure under eddy influence. Journal of Geophysical Research: Oceans, 124, 5952-5978. https://doi.org/ 10.1029/2018JC014661

Androulidakis, Y. S., Kourafalou, V. H., \& Le Hénaff, M. (2014). Influence of frontal cyclones evolution on the 2009 (Ekman) and 2010 (Franklin) Loop Current eddy detachment events. Ocean Science, 10(947-965), 6. https://doi.org/10.5194/os-10-947-2014

Athié, G., Candela, J., Ochoa, J., \& Sheinbaum, J. (2012). Impact of Caribbean cyclones on the detachment of Loop Current anticyclones. Journal of Geophysical Research, 117, C03018. https://doi.org/10.1029/2011JC007090

Baur, D. C., Rally, H. D., \& Jensen, M. M. (2017). Cooperative conservation: Strengthening US-Cuba-Mexico relations through joint management of marine protected areas in the Gulf of Mexico. Tulane Environmental Law Journal, 31, 173. https://doi.org/10.2307/ 90021696

Chen, S., Hu, C., Barnes, B. B., Xie, Y., Lin, G., \& Qiu, Z. (2019). Improving ocean color data coverage through machine learning. Remote Sensing of Environment, 222, 286-302. https://doi.org/10.1016/j.rse.2018.12.023

Chérubin, L. M., Morel, Y., \& Chassignet, E. P. (2006). Loop Current ring shedding: The formation of cyclones and the effect of topography. Journal of Physical Oceanography, 36, 569-591. https://doi.org/10.1175/JPO2871.1

de Boyer Montégut, C., Madec, G., Fischer, A. S., Lazar, A., \& Iudicone, D. (2004). Mixed layer depth over the global ocean: An examination of profile data and a profile-based climatology. Journal of Geophysical Research, 109, C12003. https://doi.org/10.1029/2004JC002378

Dukhovskoy, D. S., Leben, R. R., Chassignet, E. P., Hall, C. A., Morey, S. L., \& Nedbor-Gross, R. (2015). Characterization of the uncertainty of Loop Current metric using a multidecadal numerical simulation and altimeter observations. Deep Sea Research Part I: Oceanographic Research Papers, 100, 140-158. https://doi.org/10.1016/j.dsr.2015.01.005

Fratantoni, P. S., Lee, T. N., Podesta, G. P., \& Muller-Karger, F. (1998). The influence of Loop Current perturbations on the formation and evolution of Tortugas eddies in the southern Straits of Florida. Journal of Geophysical Research, 103(C11), 24,759-24,779. https://doi.org/ 10.1029/98JC02147

Gordon, A. (1967). Circulation of the Caribbean Sea. Journal of Geophysical Research, 72, 6207-6223. https://doi.org/10.1029/ JZ072i024p06207

Gula, J., Molemaker, M. J., \& McWilliams, J. C. (2016). Topographic generation of submesoscale centrifugal instability and energy dissipation. Nature Communications, 7, 12,811. https://doi.org/10.1038/ncomms12811

Hu, C., Lee, Z., \& Franz, B. (2012). Chlorophyll a algorithms for oligotrophic oceans: A novel approach based on three-band reflectance difference. Journal of Geophysical Research, 117, C01011. https://doi.org/10.1029/2011JC007395

Hu, C., \& Muller-Karger, F. E. (2008). On the connectivity and "black water" phenomena near the FKNMS: A remote sensing perspective. In F. L. Key West, B. D. Keller, \& F. C. Wilmot (Eds.), Connectivity: Science, people and policy in the Florida Keys National Marine Sanctuary. Colloquium proceedings, 19-21 August 2004 (pp. 47-55). Silver Spring, MD: Marine Sanctuaries Conservation Series NMSP08-02. U.S. Department of Commerce, National Oceanic and Atmospheric Administration; National Marine Sanctuary Program.

Kourafalou, V., Androulidakis, Y., Le Hénaff, M., \& Kang, H.-S. (2017). The dynamics of Cuba Anticyclones (CubANs) and interaction with the Loop Current/Florida Current system. Journal of Geophysical Research: Oceans, 122, 7897-7923. https://doi.org/10.1002/ 2017JC012928

Le Hénaff, M., Kourafalou, V. H., Dussurget, R., \& Lumpkin, R. (2014). Cyclonic activity in the eastern Gulf of Mexico: Characterization from along-track altimetry and in situ drifter trajectories. Progress in Oceanography, 120, 120-138. https://doi.org/10.1016/j.pocean.2013.08.002

Le Hénaff, M., Kourafalou, V. H., Morel, Y., \& Srinivasan, A. (2012). Simulating the dynamics and intensification of cyclonic Loop Current frontal eddies in the Gulf of Mexico. Journal of Geophysical Research, 117, C02034. https://doi.org/10.1029/2011JC007279

Leben, R. R. (2005). Altimeter-derived Loop Current metrics. In W. Sturges, \& A. Lugo-Fernandez (Eds.), Circulation in the Gulf of Mexico: Observations and models (pp. 181-201). Washington, DC: American Geophysical Union.

Lilly, J. M., \& Rhines, P. B. (2002). Coherent eddies in the Labrador Sea observed from a mooring. Journal of Physical Oceanography, 32(2), 585-598. https://doi.org/10.1175/1520-0485(2002)032<0585:CEITLS $>2.0 . C O ; 2$

Lilly, J. M., Scott, R. K., \& Olhede, S. C. (2011). Extracting waves and vortices from Lagrangian trajectories. Geophysical Research Letters, 38 , L23605. https://doi.org/10.1029/2011GL049727

Lugo-Fernandez, A., \& Leben, R. R. (2010). On the linear relationship between Loop Current retreat latitude and eddy separation period. Journal of Physical Oceanography, 40, 2778-2784. https://doi.org/10.1175/2010JPo4354.1

Lumpkin, R., \& Pazos, M. (2007). Measuring surface currents with Surface Velocity Program drifters: The instrument, its data, and some recent results. In A. Griffa (Ed.), Lagrangian analysis and prediction of coastal and ocean dynamics (pp. 39-67). Cambridge, UK: Cambridge Univ. Press.

McGillicuddy, D. J. Jr., Robinson, A. R., Siegel, D. A., Jannasch, H. W., Johnson, R., Dickey, T. D., et al. (1998). Influence of mesoscale eddies on new production in the Sargasso Sea. Nature, 394(6690), 263. https://doi.org/10.1038/28367

Miloslavich, P., Díaz, J. M., Klein, E., Alvarado, J. J., Díaz, C., Gobin, J., et al. (2010). Marine biodiversity in the Caribbean: Regional estimates and distribution patterns. PLOS ONE, 5(8), e11916. https://doi.org/10.1371/journal.pone.0011916

Muller-Karger, F. E., Walsh, J. J., Evans, R. H., \& Meyers, M. B. (1991). On the seasonal phytoplankton concentration and sea surface temperature cycles of the Gulf of Mexico as determined by satellites. Journal of Geophysical Research, 96(C7), 12,645-12,665. https://doi. org/10.1029/91JC00787

O'Reilly, J. E., Hooker, S. B., Firestone, E., O'Brien, M. C., Siegel, D. A., Toole, D., et al. (2000). SeaWiFS postlaunch calibration and validation analyses, Part 3. In NASA Tech. Memo (Vol. 11, pp. 195-222). NASA, TM-2000-206892.

Otis, D. B., Le Hénaff, M., Kourafalou, V. H., McEachron, L., \& Muller-Karger, F. E. (2019). Mississippi River and Campeche Bank (Gulf of Mexico) episodes of cross-shelf export of coastal waters observed with satellites. Remote Sensing, 11(6), 723. https://doi.org/10.3390/ rs11060723 
Schiller, R. V., \& Kourafalou, V. H. (2014). Loop Current impact on the transport of Mississippi River waters. Journal of Coastal Research, 30(6), 1287-1306. https://doi.org/10.2112/JCOASTRES-D-13-00025.1

Schmitz, W. J. (2005). Cyclones and westward propagation in the shedding of anticyclonic rings from the Loop Current. In W. Sturges, \& A Lugo-Fernandez (Eds.), Circulation in the Gulf of Mexico: Observations and models (pp. 241-261). Washington, DC: American Geophysical Union.

Smith, R. H., Johns, E. M., Goni, G. J., Trinanes, J., Lumpkin, R., Wood, A. M., et al. (2014). Oceanographic conditions in the Gulf of Mexico in July 2010, during the Deepwater Horizon oil spill. Continental Shelf Research, 77, 118-131. https://doi.org/10.1016/j.csr.2013.12.009

Soto, I., Andrefouet, S., Hu, C., Muller-Karger, F. E., Wall, C. C., Sheng, J., \& Hatcher, B. G. (2009). Physical connectivity in the Mesoamerican barrier reef system inferred from 9 years of ocean color observations. Coral Reefs, 28(2), 415-425. https://doi.org/10.1007/ s00338-009-0465-0

Valderrama, S. P., Ávila, A. H., Méndez, J. G., Martínez, O. M., Rojas, D. C., Azcona, F., et al. (2018). Marine protected areas in Cuba. Bulletin of Marine Science, 94(2), 423-442. https://doi.org/10.5343/bms.2016.1129

Vukovich, F. M., \& Maul, G. A. (1985). Cyclonic eddies in the eastern Gulf of Mexico. Journal of Physical Oceanography, 15(105-117). https://doi.org/10.1175/1520-0485(1985)015<0105:CEITEG >2.0.CO;2

Walker, N. D., Leben, R. R., \& Balasubramanian, S. (2005). Hurricane-forced upwelling and chlorophyll a enhancement within cold-core cyclones in the Gulf of Mexico. Geophysical Research Letters, 32, L18610. https://doi.org/10.1029/2005GL023716

Welsh, S. E., Inoue, M., Rouse, L. J. Jr., \& Weeks, E. (2009). Observation of the deepwater manifestation of the Loop Current and Loop Current rings in the eastern Gulf of Mexico. OCS Study MMS, 50, 110.

Wenzel, L., Cid, G., Haskell, B., Clark, A., Quiocho, K., Kiene, W., et al. (2019). You can choose your relatives: Building marine protected area networks from sister sites. Aquatic Conservation: Marine and Freshwater Ecosystems, 29, 152-161. https://doi.org/10.1002/aqc.3041

Zavala-Hidalgo, J., Gallegos-García, A., Martinez-López, B., Morey, S. L., \& O'Brien, J. (2006). Seasonal upwelling on the western and southern shelves of the Gulf of Mexico. Ocean Dynamics, 56(333-338), 3-4. https://doi.org/10.1007/s10236-006-0072-3

Zavala-Hidalgo, J., Morey, S. L., \& O'Brien, J. J. (2002). On the formation and interaction of cyclonic eddies with the Loop Current using NCOM and a suite of observations. In Proceedings of the Oceans 2002 MTS/IEEE Conference (pp. 1463-1466). Piscataway, NJ: IEEE Catalog Num. 02CH37362C.

Zavala-Hidalgo, J., Morey, S. L., \& O'Brien, J. J. (2003). Cyclonic eddies northeast of the Campeche Bank from altimetry data. Journal of Physical Oceanography, 33, 623-629. https://doi.org/10.1175/1520-0485(2003)033<0623:cenotc >2.0.co;2

Zavala-Hidalgo, J., Morey, S. L., O'Brien, J. J., \& Zamudio, L. (2006). On the Loop Current eddy shedding variability. Atmosfera, 19(1), 41-48. 